Review

\title{
Advanced and Emerging Negative Electrodes for Li-Ion Capacitors: Pragmatism vs. Performance
}

\author{
Samson Yuxiu Lai ${ }^{1, * \mathbb{D}}$, Carmen Cavallo ${ }^{2} \mathbb{D}$, Muhammad E. Abdelhamid ${ }^{1}$, Fengliu Lou ${ }^{3, *}$ and \\ Alexey Y. Koposov 1,2,*iD \\ 1 Battery Technology Department, Institute for Energy Technology (IFE), 2007 Kjeller, Norway; \\ Muhammad.Abdelhamid@ife.no \\ 2 Center for Materials Science and Nanotechnology, Department of Chemistry, University of Oslo, \\ P.O. Box 1033, Blindern, 0371 Oslo, Norway; carmen.cavallo@smn.uio.no \\ 3 Beyonder AS, 4313 Stavanger, Norway \\ * Correspondence: Samson.Yuxiu.Lai@ife.no (S.Y.L.); fengliu@beyonder.no (F.L.); \\ alexey.koposov@kjemi.uio.no (A.Y.K.)
}

check for updates

Citation: Lai, S.Y.; Cavallo, C.;

Abdelhamid, M.E.; Lou, F.; Koposov, A.Y. Advanced and Emerging Negative Electrodes for Li-Ion Capacitors: Pragmatism vs.

Performance. Energies 2021, 14, 3010. https://doi.org/10.3390/en14113010

Academic Editor: Prodip K. Das

Received: 14 April 2021

Accepted: 18 May 2021

Published: 22 May 2021

Publisher's Note: MDPI stays neutral with regard to jurisdictional claims in published maps and institutional affiliations.

Copyright: (c) 2021 by the authors. Licensee MDPI, Basel, Switzerland. This article is an open access article distributed under the terms and conditions of the Creative Commons Attribution (CC BY) license (https:/ / creativecommons.org/licenses/by/ $4.0 /)$.

\begin{abstract}
Li-ion capacitors (LICs) are designed to achieve high power and energy densities using a carbon-based material as a positive electrode coupled with a negative electrode often adopted from Li-ion batteries. However, such adoption cannot be direct and requires additional materials optimization. Furthermore, for the desired device's performance, a proper design of the electrodes is necessary to balance the different charge storage mechanisms. The negative electrode with an intercalation or alloying active material must provide the high rate performance and long-term cycling ability necessary for LIC functionality - a primary challenge for the design of these energystorage devices. In addition, the search for new active materials must also consider the need for environmentally friendly chemistry and the sustainable availability of key elements. With these factors in mind, this review evaluates advanced and emerging materials used as high-rate anodes in LICs from the perspective of their practical implementation.
\end{abstract}

Keywords: Li-ion capacitor; negative electrode; anode; prelithiation; key performance indicators

\section{Introduction}

Li-ion batteries (LIBs) have attracted worldwide attention and recognition, including a Nobel Prize in 2019, due to their immense impact on our society [1-4]. LIBs can be used in a wide range of applications, including transportation, portable devices and stationary energy storage. The relatively high gravimetric energy density (between 150 to $300 \mathrm{Wh} \mathrm{kg}^{-1}$ in commercial cells) is obtained by the intercalation/insertion of $\mathrm{Li}^{+}$ions in the active materials of electrodes. Unfortunately, the use of materials whose operation is based on intercalation/insertion principles is challenging for applications requiring high power densities, due to their slow kinetics [5].

Conversely, supercapacitors (SCs) are devices capable of high-power delivery, high stability at the cost of lower energy density, with commercial devices providing $\sim 5 \mathrm{Wh} \mathrm{kg}^{-1}$. In SCs, the energy storage process is based on the physical separation of charges at the surface of porous electrodes, forming an electrical double layer (EDL). To distinguish the storage mechanisms of LIBs and SCs, intercalation/insertion capacity is used as the performance characteristic of LIBs and their active materials, while the term "capacitance" is used for SCs [6]. Recently, the pursuit of higher power in LIBs and higher energy in SCs have directed these two technologies towards each other, resulting in devices that can offer a compromise between energy and power [7]. Among them is a hybrid asymmetric supercapacitor (HASC), which combines one electrode from a LIB and another from a SC in a single energy-storage device [8].

The terminology for these devices, like for any emerging field, can be varied, ambiguous, and/or prone to redundancy. "Supercapacitor" or "ultracapacitor" are equivalent to 
"electrochemical capacitor", which distinguishes itself from the conventional parallel plate capacitor by utilizing high surface area electrodes and capacitance from the Helmholtz EDL. The terms "hybrid supercapacitor" or "asymmetric supercapacitor" originate from the idea of a supercapacitor electrode being hybridized with a bulk Faradaic battery electrode and tends to be the broadest categorization of devices with "high energy" (i.e., relative to conventional SCs) and "high power" (i.e., relative to conventional, high-energy LIBs). As general terms, they can include aqueous and non-aqueous electrolytes and different cations ( $\mathrm{Li}, \mathrm{Na}, \mathrm{K}$, etc.) for energy storage. Another distinction should be made with "pseudocapacitors", which utilize at or near-surface redox reactions to store charge while presenting supercapacitor-like electrochemical behavior. The term "hybrid supercapacitor" should also be differentiated from a "hybrid (energy-storage) system", which is a combination of energy-storage technologies using individually distinct but coordinated devices [9].

Among HASCs, Li-ion capacitors (LICs) can achieve both high power and acceptable energy densities by using a porous EDL material as the positive electrode coupled with a Li-ion intercalation/alloying material as the negative electrode [10]. LICs provide a rational compromise between high energy and high power, making this approach an attractive energy-storage solution for certain applications. "Li-ion capacitor" is a popular term for a more specific kind of the same device and may be leveraging the prevalence of " $\mathrm{Li}$-ion battery" to render familiarity with and trust in the concept. In recent years, LICs have become the most popular title for this approach and, therefore, will be used in the present review. Overall, LICs are also mentioned in the literature as hybrid capacitors, hybrid Li-ion capacitors, supercabattery or supercapattery [11].

While there are already a substantial number of published reviews covering the wide range of materials for Li-ion and Na-ion capacitors [12-19] as well as main principles of functionality $[20,21]$, the focus of the present review is primarily devoted to the materials which have demonstrated the potential for commercial utilization in the nearest future, with exception to a few promising material classes that are on the horizon but rapidly developing. From such a perspective, the selection of practical cathode materials at the present moment is limited to activated carbon $[13,15,22]$. However, a wider selection of potential pragmatic anode materials could be adopted from the well-developed field of LIBs. In this review, LIC technology is first discussed in the context of the landscape of electrochemical energy-storage technologies, followed by universal considerations for prelithiation. Next, anodes based on commercially relevant metal oxides, silicon- and carbon-based materials and promising emerging materials are presented, with each section ending with an assessment of the commercialization challenges associated with enabling a practical LIC technology.

\section{Li-Ion Capacitors (LICs) as an Electrochemical Energy-Storage Technology}

\subsection{Comparative Performance}

The comparative performance of LICs in the context of LIBs and SCs is typically represented in a Ragone plot as shown in Figure 1, which demonstrates the relationship between power and energy density for a given technological approach. Ragone plots are often used in literature to compare the performance of different electrochemical energy storage technologies; however, they could be used for comparison of other energy storage technologies as well $[23,24]$. Ragone plots are frequently used to highlight the compromises between energy and power, particularly emphasizing the benefits of LICs compared to LIBs and SCs in the majority of LIC-related publications. Ragone plots can also be useful for studying trends over time, such as the aforementioned converging trends of a higher power in LIBs and higher energy in SCs. 


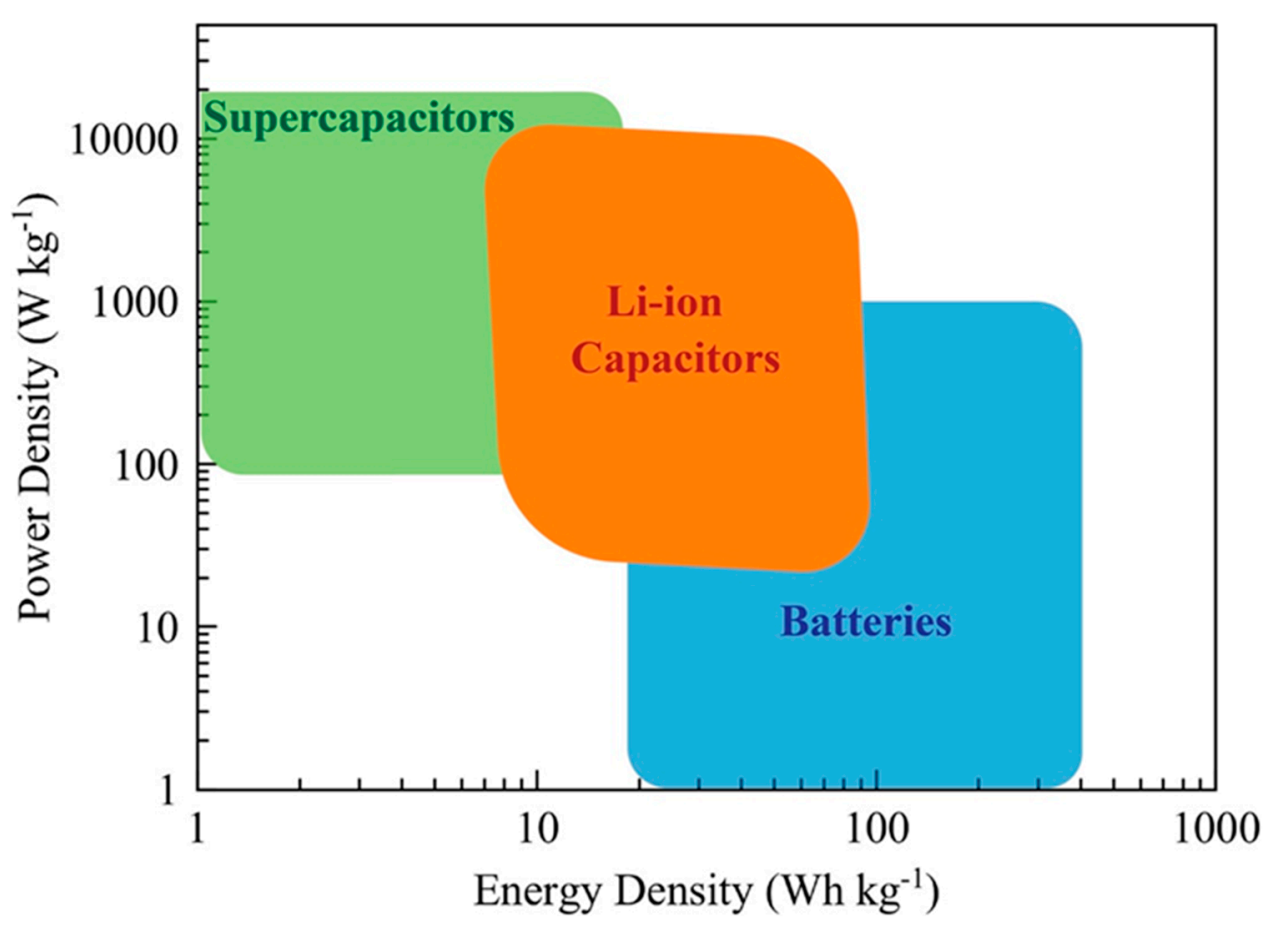

Figure 1. Qualitative Ragone plot reported in normalized terms of mass of the whole device. The shaded areas are reported in gravimetric terms.

However, the Ragone plot can be only used for qualitative comparisons of technological approaches and research results. While the anticipated principle of the Ragone plot was to provide a platform for qualitative comparison, particularly for the uninitiated in the field of energy storage, a variety of results reported over the past decades have led to substantial complications. Specifically, the information presented on the Ragone plot often does not account for the complete set of factors determining the position of a device on the plot. While the data presented for commercial cell and industrial prototypes always account for the total weight of the components, energy-storage devices fabricated and assessed in the research environment often consider only the weight of the active materials. Such differences in weight assessment results in differences in power and energy densities and, as a result, different positions of data on the Ragone plot. Furthermore, additional factors, such as cycling profile, testing temperature and others, also influence performance but are not well represented in Ragone plots.

Thus, while a Ragone plot can be used here to visualize the energy and power performance of LICs in relation to LIBs and SCs, it can unfortunately only address a limited number of aspects. It also omits important information which is extremely valuable for modern energy technologies, such as safety, natural abundance of the elements and materials, environmental side effects, cost, etc. The performance information is further limited by the caveats on calculating based on the weight of the device or active materials. Therefore, we conclude that Ragone plots are good for educational outreach to the public or for end-users who are not familiar with the breadth of energy storage technology solutions available to them. However, for researchers or companies involved in the production of energy storage materials or cells composed thereof, Ragone plots obscure important information when making comparisons between materials and technologies of interest. In addition to Ragone plots, complementary charts such as spider web diagrams and/or a list of key performance indicators (KPIs) should be used for evaluating and comparing specific materials. Special attention should be given to the reporting of new materials according to recently suggested good practices $[25,26]$. At the end of the present review, the KPIs for a few of the most promising materials are tabulated as an example. 


\subsection{Prelithiation}

Due to the LIC's hybrid nature, it often requires a supply of Li prior to cell assembly to ensure proper functionality: unlike LIBs, neither positive nor negative electrodes of LICs typically contain Li in their structure. Therefore, Li needs to be supplied to the cell through the process of prelithiation, i.e., a process of delivering Li into the active material prior to cell assembly. All materials described in the present review except for a few specific examples were subjected to prelithiation. Several prelithiation pathways have been proposed in the literature $[27,28]$ and can be briefly summarized as follows:

1. Electrochemical (in situ and ex situ);

2. Short circuit (in situ and ex situ);

3. Stabilized Li metal powder;

4. Chemical.

One of the most common methods for prelithiation in laboratory conditions mentioned in the literature is the ex situ electrochemical method, when the material of study is electrochemically lithiated against metallic Li prior to cell assembly - this versatile method could be conveniently used for any material. However, such approach is generally not scalable as it requires cell disassembly after the prelithiation and reassembly for further electrochemical function. Therefore, only in situ methods should be considered as scalable and industrially relevant. However, despite the promising results reported, the practical application of such prelithiation strategies is still questionable. For instance, in situ electrochemical prelithiation requires a sacrificial Li electrode to be incorporated into the pouch cell [29], which may complicate the assembly process at the industrial level.

Short circuit (in situ and ex situ) methods are based on forming a direct contact between anode and Li metal and can be implemented by a variety of methods [27]. However, the control of the prelithiation degree achieved with such methods is still questionable on any scale beyond the laboratory. Furthermore, the side effects of this rapid influx of Li would need study to avoid any detrimental consequences. Stabilized Li metal powder is similar to an in situ short circuit method, except the Li is encapsulated by a coating to improve its handling stability in dry-room assembly and this coating is later broken to expose the inner $\mathrm{Li}$.

While methods 1-3 were covered in a recent review [27] and are widely explored for their scalability, chemical prelithiation is a rather new process and, therefore, only a few recent research works cover this topic [28,30]. This process uses reactive species for the lithiation of an active material, delivering the simplicity and theoretical scalability of the chemical prelithiation which makes this process appealing for further development and potential implementation. Therefore, the authors believe that while the chemical background for prelithiation already exists at the large scale, it still remains an engineering feat yet to be completed.

\section{Materials Based on Metal Oxides}

Based on the early and comprehensive development of LIB materials, transition metal oxides have gained significant attention as potential anode candidates for LICs due to their low cost, high stability and simplicity of preparation [17]. The readiness and availability of these materials potentially make them materials of choice for efficient LICs. However, their low electrical conductivity, uncontrolled volumetric expansion and sluggish ion diffusion in the bulk phase have hindered their practical applications [31]. Therefore, tailoring their composition and morphology to overcome these undesired drawbacks is a key requirement for the successful implementation of these materials in practical LICs. Furthermore, it should be noted that unless stated otherwise, all metal oxides covered herein were electrochemically prelithiated prior to LIC assembly.

\subsection{Titanium-Based Oxides}

Due to their availability, fast surface redox reactions and high capacity retention, titanium-based oxides are the most studied insertion materials for LICs [32]. For instance, 
spinel $\mathrm{Li}_{4} \mathrm{Ti}_{5} \mathrm{O}_{12}$ (LTO) was extensively evaluated as an anode material for LICs due to its nearly zero strain during $\mathrm{Li}^{+}$insertion/extraction, higher lithiation potential $(1.55 \mathrm{~V}$ vs. $\left.\mathrm{Li}^{+} / \mathrm{Li}\right)$ than graphite $\left(0.07\right.$ and $0.1 \mathrm{~V}$ vs. $\left.\mathrm{Li}^{+} / \mathrm{Li}\right)$ [19], excellent chemical stability and cyclability [33]. However, the main drawback of LTO remains its poor electronic conductivity. To mitigate this issue, Liang et al. synthesized hierarchically structured LTO nanoparticles embedded in mesoporous carbon spheres (n-LTO@MC) to achieve LICs with ultrafast performance [34]. Such material combined with activated carbon (AC) as the counter electrode achieved a LIC cell with high-capacity retention for over 1000 cycles charged/discharged at $100 \mathrm{C}$ and $1000 \mathrm{C}$, as illustrated in Figure 2.

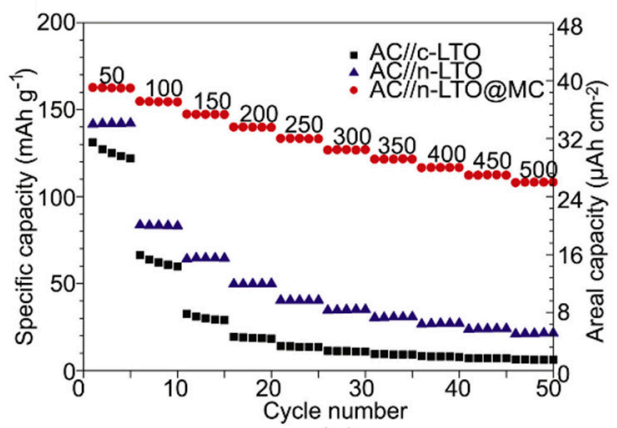

(a)

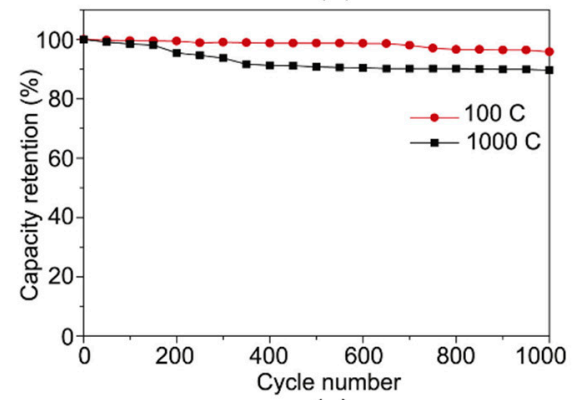

(c)

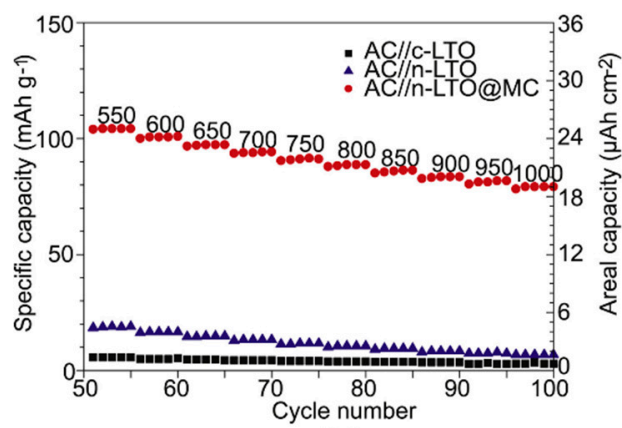

(b)

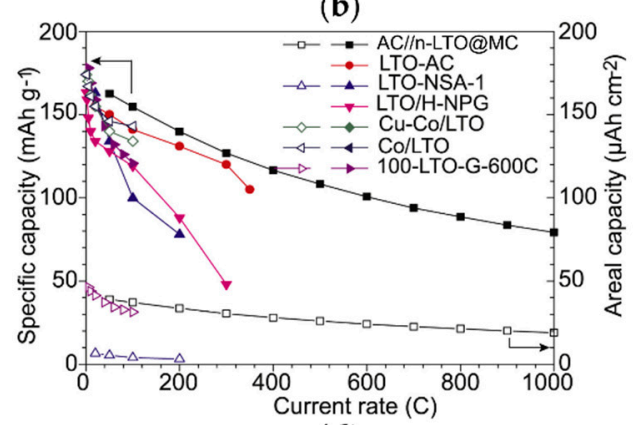

(d)

Figure 2. $(\mathbf{a}, \mathbf{b})$ Rate performances of $\mathrm{AC} / / \mathrm{c}-\mathrm{LTO}, \mathrm{AC} / / \mathrm{n}-\mathrm{LTO}$, and AC//n-LTO@MC asymmetric capacitors. Charge/discharge tests of the Li-ion capacitors (LICs) at current rates ranging from 50 to $1000 \mathrm{C}$. The valued are calculated based on the theoretical capacity of LTO and the active mass in the electrodes. More info reported in section 2.3 of [34]; (c) Capacity retention of AC//n-LTO@MC over 1000 cycles at 100 and 1000 C; (d) Performance comparison of AC//n-LTO@MC and recently reported LTO-based high-rate LICs including LTO encapsulated in activated carbon(LTO-AC) [35], self-supported LTO nanosheet arrays (LTO-NSA) [36], LTO wrapped in nanoperforated graphene (LTO/H-NPG) [37], LTO supported on pine-needle-like Cu-Co skeletons (Cu-Co/LTO) [38], LTO combined with metallic Co cores (Co/LTO) [39], and LTO deposited on graphene (LTO-G) [40] (filled symbols: specific capacities; hollow symbols: areal capacities). Adapted from [34].

Titanium dioxide $\left(\mathrm{TiO}_{2}\right)$ polymorphs, particularly anatase and bronze polymorphs, were also examined as potential anode materials for LICs as they benefit from low cost, abundance, environmental benignity, and improved stability [41]. However, the initial irreversible capacity of $\mathrm{TiO}_{2}$ limits its practical implementation. To address this issue, Calcagno et al. reported a tailored hybrid morphology for anatase $\mathrm{TiO}_{2}$ [32]. Mesoporous beads of anatase $\mathrm{TiO}_{2}$ were used as a negative electrode in a fast-charging LIC, with commercial activated carbon (AC) as the positive electrode with a conventional LIB electrolyte (LP30 : $1 \mathrm{M} \mathrm{LiPF}_{6}$ in ethylene carbonate/dimethyl carbonate (EC : DMC, $\left.50: 50 \mathrm{v} / \mathrm{v}\right)$ ). By wisely limiting the charging cutoff voltage of the $\mathrm{TiO}_{2}$ electrode, they could avoid initial capacity loss and improved cycling stability. The resulting device delivered $37 \mathrm{mWh} \mathrm{g}^{-1}$ at $0.5 \mathrm{~A} \mathrm{~g}^{-1}\left(100 \mathrm{~mW} \mathrm{~g}{ }^{-1}\right)$ and almost $10 \mathrm{mWh} \mathrm{g}^{-1}$ at a rather high current of $20 \mathrm{~A} \mathrm{~g}^{-1}$ $\left(3 \mathrm{~W} \mathrm{~g}^{-1}\right)$. Furthermore, such a LIC showed remarkably stable performance with no de- 
crease in specific energy over 10,000 cycles, which was achieved by a gradual shift to higher potentials counterbalancing a gradual decrease in capacity. Notably, the formation of cubic $\mathrm{LiTiO}_{2}$ nanocrystals on the surface of the mesoporous $\mathrm{TiO}_{2}$ beads as a result of cycling was confirmed by transmission electron microscopy (TEM) analysis of the post-cycled electrodes. The formation of the thin layer of $\mathrm{LiTiO}_{2}$ (which essentially participates in the electrochemical activity) allows in situ lithiation of the anatase beads, avoiding the prelithiation step conventionally used in LICs.

$\mathrm{TiO}_{2}$ forms a benign interface with LTO, offering grain boundaries as locations to further increase $\mathrm{Li}^{+}$storage. The benefits of such $\mathrm{LTO}-\mathrm{TiO}_{2}$ combination resulted in improved electrochemical performance, which has been demonstrated by several research groups. For instance, Tian et al. prepared LTO/anatase $\mathrm{TiO}_{2}$ nanosheets anchored on reduced graphene oxide (RGO) as self-supporting electrodes to store $\mathrm{Li}^{+}$ions with a capacity of $86 \mathrm{mAh} \mathrm{g}^{-1}$ at $100{ }^{\circ} \mathrm{C}$ [42]. Furthermore, Zhu et al. reported a nanocrystalline composite, $\mathrm{LTO} / \mathrm{TiO}_{2} / \mathrm{C}$, which was capable of delivering a discharge capacity of $88 \mathrm{mAh} \mathrm{g}^{-1}$ at $30{ }^{\circ} \mathrm{C}$ [43]. Using similar principles, Zouh et al. utilized a carbon foam as a conductive matrix for a $\mathrm{LTO}-\mathrm{TiO}_{2}$ composite (CF@LTO-TO), studying the performance of the device and self-discharge at the same time [44]. The electrodes with high mass loading of $\mathrm{LTO}^{-\mathrm{TiO}_{2}}$ composite ( 25 and $45 \mathrm{wt} \%$ ) exhibited substantially improved rate performance compared to those with lower mass loadings. The slowest self-discharge was achieved in LICs having electrodes with $45 \mathrm{wt} \%$ of LTO-TO, which showed a low leakage current of $5.75 \mathrm{~mA} \mathrm{~g}^{-1}$ and an open circuit voltage (OCV) drop from 2.5 to $1.1 \mathrm{~V}$ after one week.

\subsection{Niobium-Based Oxides}

Niobium oxide $\left(\mathrm{Nb}_{2} \mathrm{O}_{5}\right)$ has recently become a material of interest for high-rate anodes in LIBs [45], and therefore represents a particular interest for LICs. Niobium oxide in its orthorhombic form $\left(\mathrm{T}_{-} \mathrm{Nb}_{2} \mathrm{O}_{5}\right)$ possesses a layered structure and received substantial attention due to its unique (001) crystal plane, which provides a two-dimensional Li-ion transport channel [46]. Thus, the intercalation of $\mathrm{Li}^{+}$into $\mathrm{T}-\mathrm{Nb}_{2} \mathrm{O}_{5}$ is a pseudocapacitivetype process with rapid diffusion kinetics in the bulk without any phase transitions during lithiation/delithiation [47]. However, similarly to most transition metal oxides, $\mathrm{T}-\mathrm{Nb}_{2} \mathrm{O}_{5}$ exhibits a low electronic conductivity of $\sim 3 \cdot 10^{-6} \mathrm{~S} \mathrm{~cm}^{-1}$ at room temperature. The combination of carbon materials with $\mathrm{T}-\mathrm{Nb}_{2} \mathrm{O}_{5}$ is considered to be the most effective way to overcome the poor electronic conductivity [48-50]. Therefore, Li et al. synthesized porous $\mathrm{Nb}_{2} \mathrm{O}_{5} @ \mathrm{C}$ hollow nanospheres (3-D Nb $\mathrm{O}_{5} @ \mathrm{C}$ ), where the hollow spheres allowed shortening of the ion diffusion distance and effectively buffered volume expansion [51]. The final LIC with the electrode comprising GNC (graphitic N-doped carbon)/ $/ \mathrm{Nb}_{2} \mathrm{O}_{5} @ \mathrm{C}$ demonstrated an energy density of $96.8 \mathrm{Wh} \mathrm{kg}^{-1}$ at $435.5 \mathrm{~W} \mathrm{~kg}^{-1}$, a power density of $41 \mathrm{~kW} \mathrm{~kg}^{-1}$ at $12.6 \mathrm{Wh} \mathrm{kg}^{-1}$ and a high-capacity retention of $75 \%$ after 3000 cycles.

The challenging synthetic route for the preparation of $\mathrm{T}-\mathrm{Nb}_{2} \mathrm{O}_{5}$ is a major roadblock preventing widespread adoption of this promising material, which resulted in a search for alternatives. For instance, Quin et al. used few-layered $\mathrm{Nb}_{2} \mathrm{CT}_{\mathrm{x}}\left(\mathrm{f}-\mathrm{Nb}_{2} \mathrm{CT}_{\mathrm{x}}\right) \mathrm{MXene}$ nanosheets (NSs) as the Nb-based precursor [52]. The resultant single crystalline $\mathrm{T}_{-}-\mathrm{Nb}_{2} \mathrm{O}_{5}$ nanorods (NRs) grew along [001] crystal orientation, which possesses the minimum $\mathrm{Li}^{+}$ transport barrier. Such $\mathrm{T}-\mathrm{Nb}_{2} \mathrm{O}_{5}$ showed superior electrochemical performance unlike the pseudohexagonal phase $\left(\mathrm{TT}-\mathrm{Nb}_{2} \mathrm{O}_{5}\right)$ with the same NR morphology as demonstrated in Figure 3. 

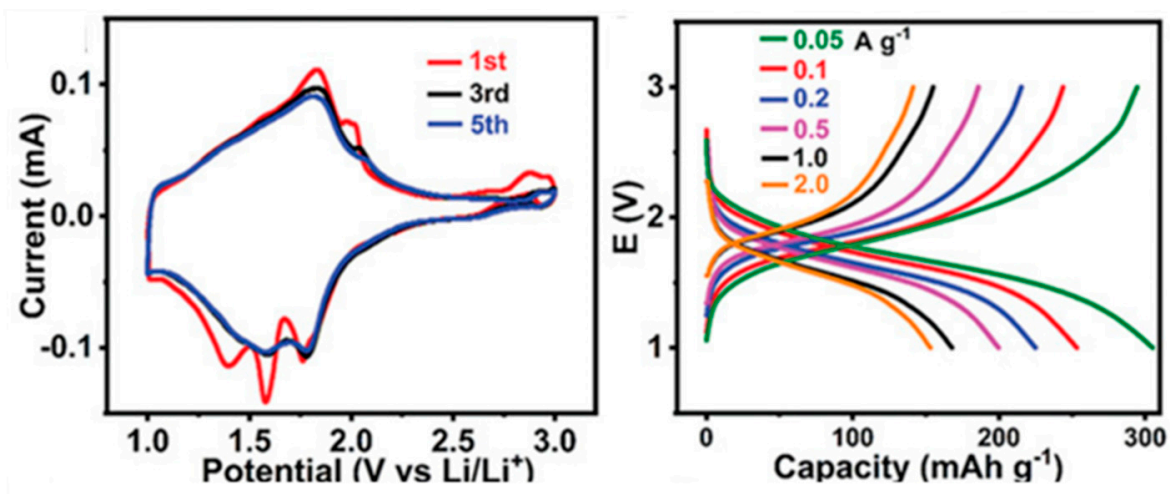

(a)

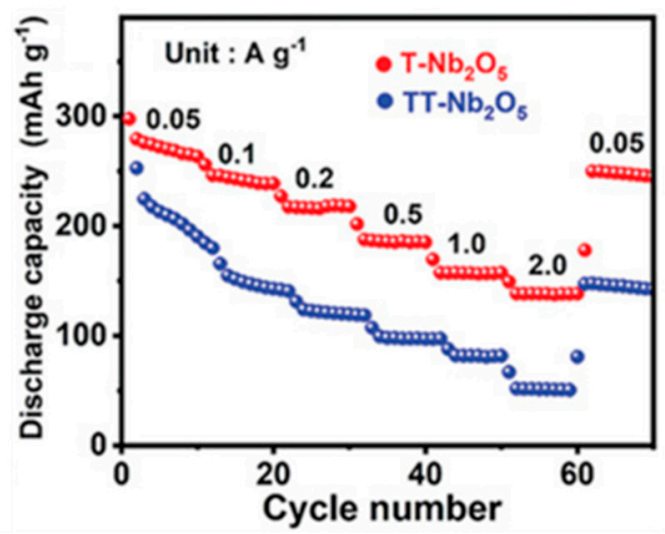

(b)

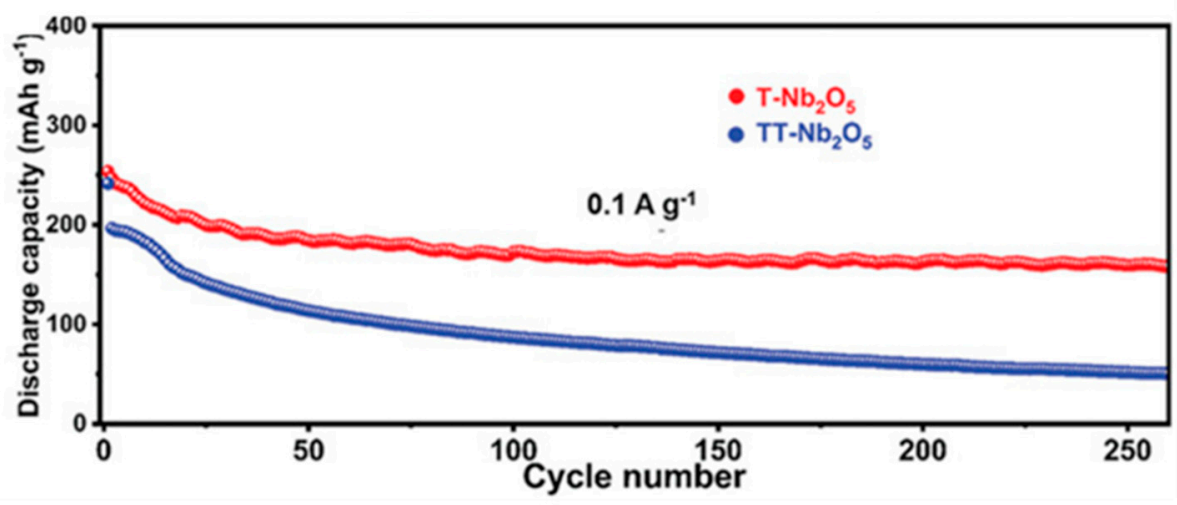

(c)

Figure 3. (a) Cycling Voltammetry (CV) curves $\left(0.1 \mathrm{mV} \mathrm{s}^{-1}\right)$ (left panel) and galvanostatic chargedischarge plots at various current densities of $\mathrm{T}-\mathrm{Nb}_{2} \mathrm{O}_{5}$ nanorods (NRs, right panel); (b) rate behaviors of $\mathrm{T}-\mathrm{Nb}_{2} \mathrm{O}_{5}$; (c) Cycling properties of $\mathrm{T}-\mathrm{Nb}_{2} \mathrm{O}_{5}$ and $\mathrm{TT}-\mathrm{Nb}_{2} \mathrm{O}_{5}$ NRs at $0.1 \mathrm{~A} \mathrm{~g}^{-1}$. Adapted from [52].

In the aforementioned niobium-based oxides, $\mathrm{Nb}^{5+}$ undergoes a single-electron reduction and becomes $\mathrm{Nb}^{4+}$ within the voltage range of 1.2-3.0 $\mathrm{V}\left(\mathrm{vs} \mathrm{Li} / \mathrm{Li}^{+}\right)$[53]. To further improve this material, the findings from LIB could be applied [54] and the $\mathrm{Nb}$ atoms could be partially replaced with Ti atoms forming titanium niobium oxides (TNO)—a material that benefits from the presence of multiple redox couples. As a result, TNO can provide theoretical capacities up to $388-397 \mathrm{mAh} \mathrm{g}^{-1}$ [55]. High $\mathrm{Li}^{+}$storage capacity and excellent 
$\mathrm{Li}^{+}$diffusivity make TNO an excellent choice for LICs. Like other oxides, they suffer from poor electronic conductivity, which is currently a major focus for improving TNO.

Recently, Yuan et al. synthesized a hierarchical $\mathrm{Ti}_{2} \mathrm{Nb}_{10} \mathrm{O}_{29}$ structure wrapped with $\mathrm{N}$ rich carbon conductive layer (TNO@NC) through polypyrrole-chemical vapor deposition (PPy-CVD). Such a material shows a remarkable performance in LICs, as it enables a high capacity of $300 \mathrm{mAh} \mathrm{g}^{-1}$ when measured at a $1 \mathrm{C}$ cycling rate, and $211 \mathrm{mAh} \mathrm{g}^{-1}$ at 100 C [56]. The ACI I TNO@NC-based hybrid LIC exhibits high energy (116.1 Wh kg-1) and power density ( $\left.3171.9 \mathrm{~W} \mathrm{~kg}^{-1}\right)$, which are "attributed to the synergistic effect of the $\mathrm{N}$-rich carbon coating, TiN-doping, formation of oxygen vacancies, and the micro-nano hierarchical architecture of the electrode, as confirmed by experimental measurements and density functional theory (DFT) based calculations" [56].

Budak et al. further improved the performance of this anode material through a composite of $\mathrm{Ti}_{2} \mathrm{Nb}_{10} \mathrm{O}_{29}$ with carbon [57]. Preliminary results in half cells (vs. Li metal) demonstrated a $350 \mathrm{mAh} \mathrm{g}^{-1}$ at a rate of $0.01 \mathrm{~A} \mathrm{~g}^{-1}\left(144 \mathrm{mAh} \mathrm{g}^{-1}\right.$ at $\left.1 \mathrm{~A} \mathrm{~g}^{-1}\right)$, illustrating the potential of this material for LICs. However, its stability is still below the requirements set by LIC's applications.

\subsection{Conversion Oxides}

A different subclass of oxide materials known as the conversion-type materials can deliver a high theoretical specific capacity (500 1000 $\mathrm{mAh} \mathrm{g}^{-1}$ ), as the reduction of transition metals in oxides to their metallic state is a multiple-electron transfer process. Moreover, the lithiation potentials of metal oxides are generally lower than that of insertion compounds, which is favorable for LIC applications. As a consequence, several conversion-type metal oxides ( $\mathrm{MnO}$ [58], $\mathrm{MoO}_{2}$ [59], $\mathrm{Fe}_{3} \mathrm{O}_{4}$ [60], $\mathrm{Fe}_{2} \mathrm{O}_{3}$ [61], $\mathrm{V}_{2} \mathrm{O}_{5}$ [62], $\mathrm{RuO}_{2}$ [63]) are considered as suitable candidates for anodes of LICs. However, similar to the insertion-type oxides described earlier, the conversion-type oxides exhibit low electronic conductivity. In addition, substantial volumetric change occurring during lithiation/delithiation is generally observed for this type of material, creating problems commonly associated with pulverization of the active material during cycling [64].

Among these materials, manganese oxide $\left(\mathrm{MnO}_{2}\right)$, has drawn considerable interest as one of the most promising electrode materials for hybrid supercapacitors owing to its ultra-high theoretical energy density ( $308 \mathrm{Wh} \mathrm{kg}^{-1}$ for a single-electron reaction), elemental abundance in the Earth's crust, and environmental friendliness [65]. Combining $\mathrm{MnO}_{2}$ with carbonaceous materials can help overcome the common problem of low conductivity. Qi et al. recently reported a mulberry-like core-shell structured $\mathrm{C} @ \mathrm{MnO}_{2}$. The material shows high capacitance up to $274.44 \mathrm{~F} \mathrm{~g}^{-1}$ under $1 \mathrm{~A} \mathrm{~g}^{-1}$ in $6 \mathrm{M} \mathrm{KOH}$ and the capacity retention is $90.2 \%$ after 5000 cycles [66].

Binary transition metal oxides (BTMOs), such as $\mathrm{NiCo}_{2} \mathrm{O}_{4}$ [67], $\mathrm{ZnMn}_{2} \mathrm{O}_{4}$ [68], $\mathrm{MnFeO}_{4}[69]$ and others, benefit from the coexistence of two different cations in a single crystal structure, which leads to improvement in the electrical conductivity and simplicity of preparation. For instance, spinel $\mathrm{NiCo}_{2} \mathrm{O}_{4}$ possesses electrical conductivity several orders of magnitude higher than that of the corresponding single metal oxides such as $\mathrm{NiO}$ or $\mathrm{Co}_{3} \mathrm{O}_{4}$ [67]. An additional benefit of BTMOs compared to single metal oxides is the compositional tuning of the metal cation ratio, which can enhance the electrical conductivity of the active material [70]. Wang et al. pushed the limitations of $\mathrm{NiCo}_{2} \mathrm{O}_{4}$ by using a core/shell structure of $\mathrm{NiCo}_{2} \mathrm{O}_{4} / \mathrm{NiCoON}$ nanowires [71]. The binder-free negative electrode was synthetized on a carbon cloth as shown in Figure 4a and demonstrated high activity for redox reactions. Owing to the synergistic effects of oxygen vacancies and massive multivalent metal cations, the optimized $\mathrm{NiCoON}$ electrode displayed substantially enhanced electronic conductivity, rate performance, and capacity $\left(1855 \mathrm{mAh} \mathrm{g}^{-1}\right.$ at $200 \mathrm{~mA} \mathrm{~g}^{-1}$ ), as shown in Figure 4b,c. 


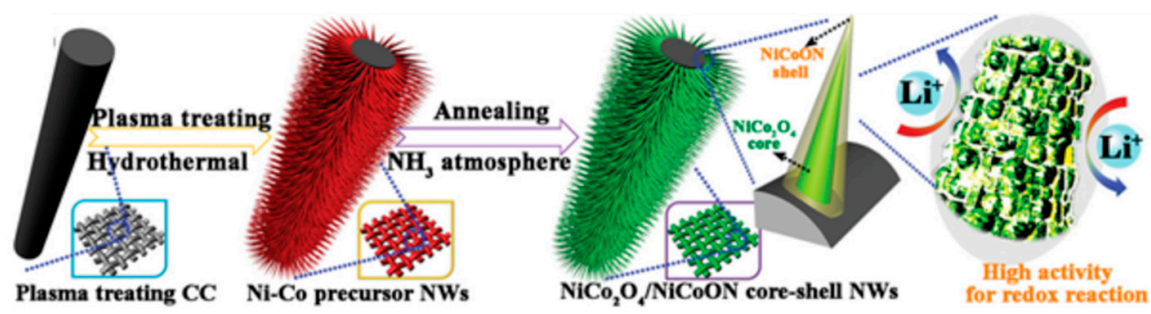

(a)

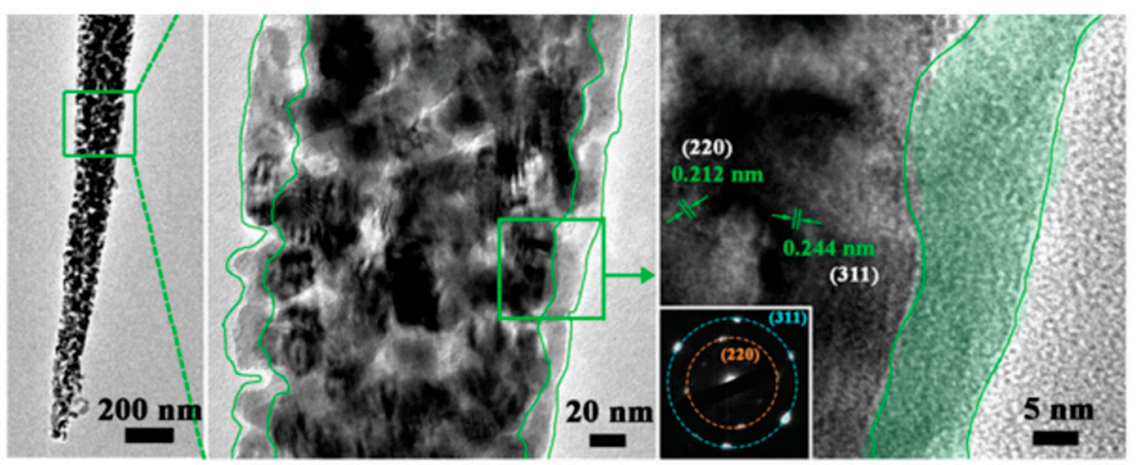

(b)
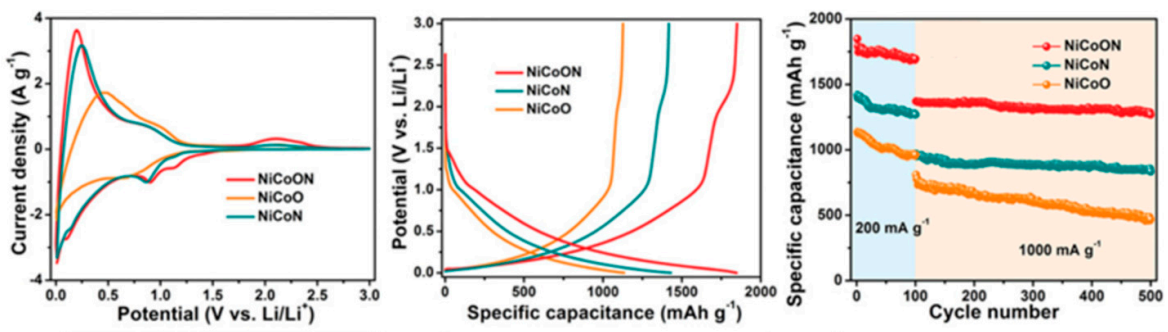

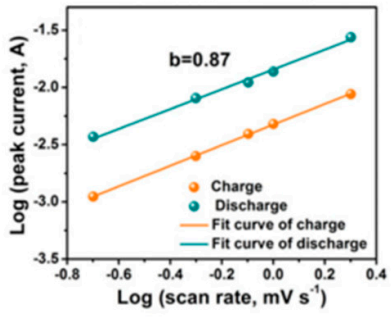

(i)

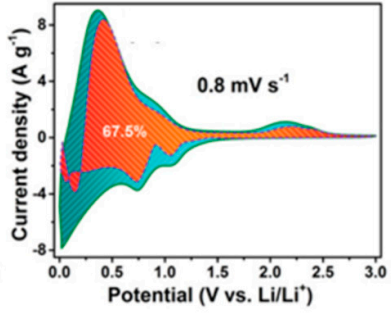

(ii)

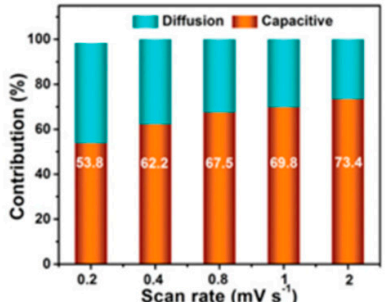

(iii)

(c)

Figure 4. (a) Schematic of the fabrication procedure of the $\mathrm{NiCo}_{2} \mathrm{O}_{4} / \mathrm{NiCoON}$ core-shell nanowires and it as electrodes for redox reaction; (b) transmission electron microscopy (TEM) images in the first to panels (from left to right) and high-resolution TEM image of NiCoON in the third. The inset shows the corresponding selected area electron diffraction (SAED) pattern. (c) Electrochemical performance of Ni-Co-based nanocomposites: CV curves at $0.1 \mathrm{mV} \mathrm{s}^{-1}$. (i) Top panel: Galvanostatic Charge/Discharge (GCD) curves at $200 \mathrm{~mA} \mathrm{~g}^{-1}$; (ii) top panel: cycling performance at 0.2 and $1.0 \mathrm{~A} \mathrm{~g}^{-1}$ for 500 cycles; (iii) top panel: relationship between the logarithm of the cathodic peak current and the logarithm of the scan rate; (i) bottom panel: separation of capacitive and diffusion current at $0.8 \mathrm{mV} \mathrm{s}^{-1}$; (ii) bottom panel: and charge storage contributions at different scan rates; (iii) bottom panel: $\mathrm{CV}$ curves of the $\mathrm{NiCO}_{2} \mathrm{O}_{4} / \mathrm{NiCoON}$ core-shell nanowires at increasing scan rate. Adapted from [71]. 
In summary, titanium and niobium-based oxides are the most promising insertion anodes for LIC. Among them, $\mathrm{T}-\mathrm{Nb}_{2} \mathrm{O}_{5}$ and $\mathrm{TNO}$ showed the highest capacity and capacity retention at rather extreme conditions (up to 100C). In particular, TNO demonstrates a very high capacity (up to $300 \mathrm{mAh} \mathrm{g}^{-1}$ ) coupled with remarkable stability. However, considering the total weight of the final device, toxicity and availability of the materials, titanium-based oxides are still highly competitive with the niobium counterparts. To utilize the full potential of these materials in commercial applications, the electrical conductivity of these materials is must be addressed.

Conversion materials offer a theoretical specific capacity $\left(500 \sim 1000 \mathrm{mAh} \mathrm{g}^{-1}\right)$ which is even higher than that for insertion oxides. $\mathrm{MnO}_{2}, \mathrm{~V}_{2} \mathrm{O}_{5}$ and $\mathrm{RuO}_{2}$ are the rational choices considering their remarkable performance in supercapacitors. However, as mentioned above, they also suffer from low electronic conductivity in addition to fast capacity fading, which originates from substantial volume change during the conversion reaction. Their performances have been improved through the addition of various carbonaceous materials and their use is not limited to LICs [72]. More promising within this class are functional structures of BMTOs, like $\mathrm{NiCo}_{2} \mathrm{O}_{4}$, which have shown a good specific capacitance at high rate, paving the way for high power density LICs.

\section{Silicon-Based Materials}

Silicon (Si) has been long viewed as a promising material for LIBs due to its high gravimetric capacity, high elemental abundance, and low delithiation potential [73]. Therefore, in the search for advanced materials for LICs, Si has become a popular choice as an active material for LICs. However, the large capacity of Si results in enormous volumetric changes associated with lithiation/delithiation processes restricting its wide deployment in LIBs. Such processes are also accompanied with constant solid electrolyte interphase (SEI) formation consuming available lithium and electrolyte [74]. In LICs however, the full capacity of $\mathrm{Si}$ is not required, thus shallow cycling of Si provides significant benefits in terms of its cycle life; however, prelithiation is required to enable this function. Furthermore, to mitigate the stability issues of $\mathrm{Si}$ and enable simple processing of the electrodes, nanostructuring has been introduced for amorphous and crystalline Si $[75,76]$. Various examples of nanostructured $\mathrm{Si}$-nanoparticles, core/shell structures, nanowires, nanotubes, and nanoporous structures-have been reported over the years to mitigate the volume expansion-caused capacity fading [77]. Binder chemistry is also of critical importance for the performance of Si-based anodes [78,79]. Another challenge of $\mathrm{Si}$ is its low electronic conductivity and poor $\mathrm{Li}^{+}$diffusion which affect high rate cycling; however, in LICs, $\mathrm{Si}$ operates in its lithiated state, partially mitigating such problems. Prelithiation plays an important role in the utilization of Si in LIC technology and could be performed through several pathways as described above.

\subsection{Pure Silicon and Silicon Nanostructures}

In 2016, Saito et al. investigated prelithiation of crystalline Si nanoparticles, demonstrating benefits of LICs over traditional electric double-layer capacitor (EDLCs) and the advantage of $\mathrm{Si}$ over conventional graphite anodes [80]. Prelithiation was achieved by direct chemical contact with a $50 \mu \mathrm{m} \mathrm{Li} \mathrm{metal} \mathrm{foil} \mathrm{immersed} \mathrm{into} \mathrm{a} \mathrm{solution} \mathrm{of} 1.0 \mathrm{M} \mathrm{LiBF}_{4}$ in propylene carbonate (PC). However, these laboratory-scale methods remain primitive and the cells, although having much higher capacity than EDLCs of activated carbon, suffer from high irreversible first cycle capacity loss and poor cyclability due to unstable SEI formation on the $\mathrm{Si}$, particularly during the chemical prelithiation process. In response to these remaining challenges, fluoroethylene carbonate (FEC), an electrolyte additive which has shown effectiveness for extending $\mathrm{Si}$ anode cycle life in LIBs, was identified as a chemical solution while vacuum pressure impregnation of the Si electrode was offered as a processing solution. Combined, these approaches delivered $114 \mathrm{Wh} \mathrm{kg}^{-1}$ electrodes (utilizing $700 \mathrm{mAh} \mathrm{g}^{\mathrm{Si}-1}$ vs. $224 \mathrm{mAh} \mathrm{g}^{-1}$ in the control sample) at $1.0 \mathrm{~mA} \mathrm{~cm}^{-2}$ after 50 cycles, demonstrating the advantages delivered by the prelithiated Si. In a following 
work, the group managed to extend the cyclability to 800 cycles by replacing sodium carboxymethyl cellulose binder with polyimide [81].

Similar to its behavior in LIBs, volume expansion of pure Si-based electrodes remains a challenge at high capacity utilization. Liu et al. have also demonstrated the performanceenhancing properties of a Si-based LIC over conventional EDLCs, using copper dome micro-patterning via transfer of a self-assembled polylactic acid thin film template and subsequent vapor deposition of the $\mathrm{Si}$ [82]. The study suggested that the larger surface area helps maintain electronic contact and binding to the electrode. For 15,000 cycles, the $1.5 \mu \mathrm{m}$ electrode paired with activated carbon, a $1 \mathrm{M} \mathrm{LiPF}_{6}$ salt, and electrochemical prelithiation achieved $90 \mathrm{Wh} \mathrm{kg}^{-1}$ at $90 \mathrm{~W} \mathrm{~kg}^{-1}$ and $55 \mathrm{Wh} \mathrm{kg}^{-1}$ at $900 \mathrm{~W} \mathrm{~kg}^{-1}$. However, such configuration, while it demonstrates the potential performance of the material, is far from practical. Likewise, the use of Si can be improved through the engineering of other components of electrodes such as binders. For instance, the use of gelatin-derived carbon as a binder and as conductive additive substantially improved the performance of LICs primarily due to the provided elasticity which delivered more structural stability to the Si-based electrode [83].

Nanowires are another type of morphology-driven innovation to handle the lifecycle challenges of $\mathrm{Si}$ and their benefits were originally demonstrated in a symmetrical cell, where Si nanowires were coated with poly(3,4-ethylenedioxythiophene) [84]. This approach was extended further by combining the nanowire structure with the flexibility of a fabric-based device [85]. Such a LIC device could deliver $210 \mathrm{Wh} \mathrm{kg}^{-1}$ at $193 \mathrm{~W} \mathrm{~kg}^{-1}$ and $43 \mathrm{Wh} \mathrm{kg}^{-1}$ at $99 \mathrm{~kW} \mathrm{~kg}{ }^{-1}$. Similar to other Si studies, a $1 \mathrm{M} \mathrm{LiPF}_{6}$ carbonate-based electrolyte and electrochemical prelithiation were used. Using a combination of $\mathrm{Si}$ and $\mathrm{Cu}$ nanowires to make a bilayer fabric can lead to significantly greater stability during full Si utilization in a half cell. However, the AC/Si ratio tuning during electrode optimization can also have a significant impact: reducing the ratio from 2 to 0.32 led to a $90 \%$ capacity retention for 30,000 cycles at $10 \mathrm{~A} \mathrm{~g}^{-1}$. However, scalability always presents itself as an issue for nanowire systems. Likewise, the prelithiation methods here are electrochemically driven with pre-cell assembly.

The performance of LICs strongly depend on the surface area of active material: $\mathrm{Si}$ could be easily etched to form a porous structure and, therefore, Si represents an excellent platform for such experimentation. A variety of scalable methods for etching Si have been developed over the years [86,87]. Thus, these techniques were evaluated for improving the performance of LICs. For instance, to demonstrate the feasibility of the approach, Oakes et al. demonstrated the use of porous Si obtained from highly doped Si wafers in a symmetrical device [88]. To improve the stability and conductivity of the porous structure, coating with graphene was performed and the symmetrical device was evaluated using 1-ethyl-3-methylimidazolium tetrafluoroborate $\left(\mathrm{EMIBF}_{4}\right)$ ionic liquid electrolytes. Despite the attractiveness of the approach, the use of ionic liquids is most likely responsible for the long term cyclability of the device. This work was further extended into more complex structures combining nanoscaling in a form of hollow spheres with controlled porosity and carbon coating [89]. Such porous Si/C ball-in-ball hollow spheres (HSs) demonstrated a discharge capacity of $586 \mathrm{mAh} \mathrm{g}^{-1}$ at a current density of $32.0 \mathrm{~A} \mathrm{~g}^{-1}$. As a result, LICs based on such materials and rice husks-based AC (RAC) were capable of providing energy densities of 239 and $154 \mathrm{~W} \mathrm{~h} \mathrm{~kg}^{-1}$ at power densities of 1376 and $\sim 69,600 \mathrm{~W} \mathrm{~kg}^{-1}$, respectively, and stable cycling performance $\left(15,000\right.$ cycles) at $6.4 \mathrm{~A} \mathrm{~g}^{-1}$ as illustrated in Figure 5. 


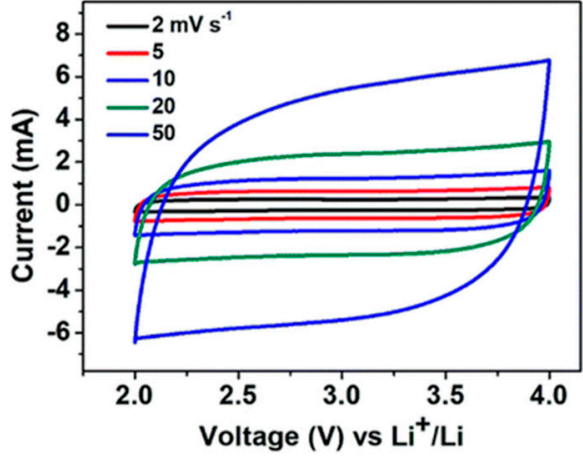

(a)

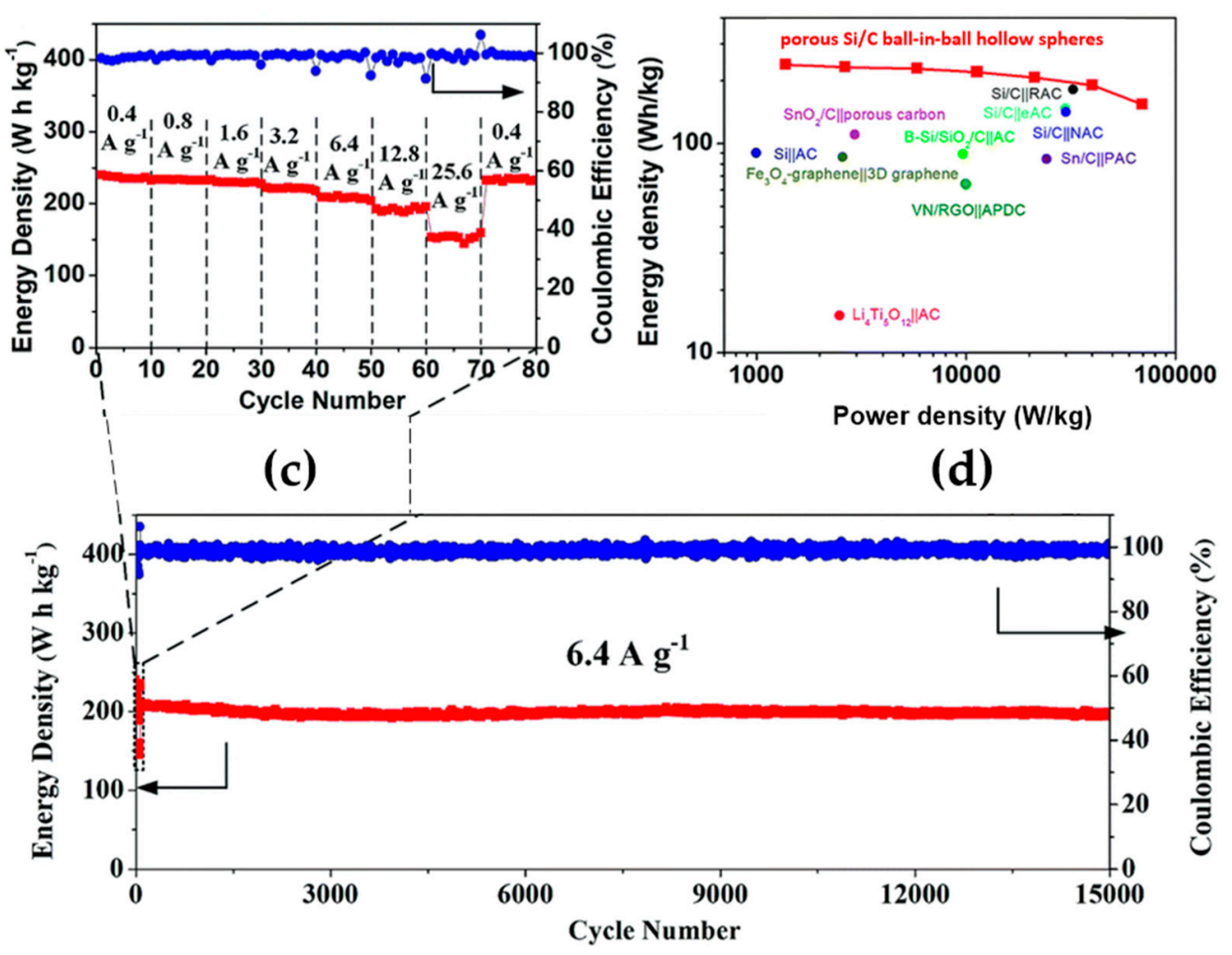

(e)

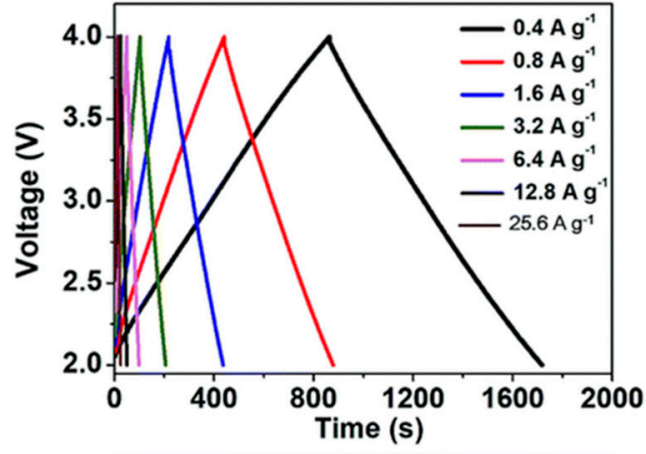

(b)

\section{)}

Figure 5. Performance of porous Si/C ball-in-ball HSs: (a) CV curves at different scan rates; (b) voltage profile; (c) rate performance; (d) Ragone plot, and (e) long cycling performance at $6.4 \mathrm{~A} \mathrm{~g}^{-1}$ of a Si@C ball-in-ball HSs $\|$ RAC LIC full cell. Adapted from [89].

A combination of Si and carbon (also often mentioned in the literature as Si/carbon composites) have been initially created for improving stability and conductivity of Si for LIBs. This approach has been deployed in LICs as well. For instance, Si-carbon composites of several compositions were fabricated to investigate their beneficial influences on the performance of LICs [90]. The results showed that the specific capacities of the anodes increased significantly by $16.6 \mathrm{mAh} \mathrm{g}^{-1}$ with $1.0 \mathrm{wt} \%$ carbon-Si composite, while the initial discharge efficiency barely changed. The specific capacity of the anode with a $10.0 \mathrm{wt} \%$ carbon-Si composite reached $513.1 \mathrm{mAh}^{-1}$, and the initial discharge efficiency was $83.79 \%$. "Furthermore, the anodes with $7.5 \mathrm{wt} \%$ or lower amounts of carbon-Si composite demonstrated reduced charge transfer resistances, which caused an improvement in the rate performance of the LICs. Moreover, the use of an optimized amount $(7.5 \mathrm{wt} \%)$ of 
$\mathrm{Si}$ /carbon composite in anode could significantly improve the cyclability of the LIC by compensating for the consumption of active Li. The capacity retention of such a LIC device reached $95.14 \%$ at $20 \mathrm{C}$ after 10,000 cycles, while the anode potential remained below $0.412 \mathrm{~V}$, which is much lower than that of a soft carbon anode. Such approach could be considered as the most promising for the industrially practical development of Si-based materials for LICs."

\subsection{Silicon-Based Composites}

Similar to the development in LIBs, Si-based materials have become a popular choice for anodes as they allow to mitigate degradation mechanisms common for pure Si [91-93]. Yi et al. designed and developed a high-rate performing anode for LIC use by combining the approaches of using size reduction by planetary milling of commercial crystalline Si nanoparticles, boron-doping by solid-state reaction, and carbon-coating via acetylene thermal pyrolysis [94]. These additions enhanced the performance to $128 \mathrm{Wh} \mathrm{kg}^{-1}$ at $1229 \mathrm{~W} \mathrm{~kg}^{-1}$, retaining $70 \%$ of capacity after 6000 cycles. Even at power demands necessary for supercapacitors of $9704 \mathrm{~W} \mathrm{~kg}^{-1}$, the hybrid supercapacitor using porous spherical carbon as the positive electrode still delivered $89 \mathrm{Wh} \mathrm{kg}^{-1}$ [91-93].

Porous silicon carbide spheres developed by Kim et al. can also serve as high capacitance electrode materials [95]. Here, utilization of both mesopores and micropores, the latter supposedly generated by partial vaporization of $\mathrm{Si}$ atoms, increased the specific surface area, defined through Brunauer Emmet and Teller (BET) method, to as much as $1713 \mathrm{~m}^{2} \mathrm{~g}^{-1}$ and $259.9 \mathrm{~F} \mathrm{~g}^{-1}$ at a scan rate of $5 \mathrm{mV} \mathrm{s}^{-1}$. However, the hydrofluoric acid rinse after the aerosol spray drying and carbonization synthesis seems to also be a plausible cause for the porosity. For a similar purpose, low carbon silicon oxycarbide (LC-SiOC) was prepared through pyrolysis of silicone oil [96]. For activation purposes, LC-SiOC needs to be prelithiated, which was performed through contact with $\mathrm{Li}$ foil in the presence of electrolyte (1 $\mathrm{M} \mathrm{LiPF}_{6}$ in a solution of ethylene carbonate/dimethyl carbonate/ethyl methyl carbonate, $1: 1: 1$, vol \%). Combining LC-SiOC with a high-surface-area alternating current (AC) electrode yielded a LIC capable of delivering a power density of up to $156 \mathrm{~kW} \mathrm{~kg}^{-1}$ while maintaining a relatively high energy density of $25 \mathrm{Wh} \mathrm{kg}^{-1}$.

When considering the aspect of practical implementation, the competitive advantages of Si are abundantly clear: low cost, widely available, low toxicity, and with a strong working knowledge and experience from other industries like semiconductors and metallurgy. These competitive advantages with its high capacity have already led it to being industrially produced and incorporated for LIBs, and soon, LICs. However, these practical examples still only contain a minor fraction of $\mathrm{Si}$ and the challenge yet remains to enhance $\mathrm{Si}$ through surface modification, composition, morphology, and/or nanoengineering to overcome the main challenges in electronic conductivity and cyclability. These necessary additional processes will dull the competitive edge of $\mathrm{Si}$ with respect to other anode materials.

\section{Organic-Based Materials}

Similar to LIB electrodes, active materials for LICs are typically inorganic as illustrated in the sections above. However, often such materials come with financial, ethical and environmental penalties that counteract the purpose of these energy-storage devices [97]. These drawbacks were the motivation for intensive research to find better alternatives. Materials for organic-based electrodes (OBEs) appeared in the early 2000s, emerging as potential contenders to replace inorganic materials in both the positive and negative electrodes. OBEs are based on naturally abundant elements, including carbon, hydrogen, oxygen, nitrogen, and sulfur, which deliver an economic immunity to resource-related challenges [98-100]. Thus, it is always possible to optimize and engineer the materials to target specific properties at low production costs. Moreover, they have several advantages, such as high specific capacities, negligible swelling upon cycling, and mechanical flexibility [101]. 
Nature gives multiple examples of suitable electrochemically active organic molecules: for example, quinones play a key role in the photosynthesis process [102]. Although the reactions responsible for their activity involve $\mathrm{H}^{+}$and electron exchange, the chemistry of these compounds is not very sensitive to the nature of the cation. Therefore, $\mathrm{H}^{+}$can be substituted with metal cations (such as $\mathrm{Li}^{+}$and $\mathrm{Na}^{+}$) to yield organic materials for electrodes of metal-ion energy storage devices. An overall blueprint of the redox-active organic molecules and their charge transfer steps adapted from Hünig's classification [103] is reported (Figure 6) [104], where X/Y are N, O, S, P, $\pi$-systems, carboxylate, anhydride, or amide functional groups. System $B$ has been shown to be more relevant for LIBs and capacitors [105-107].

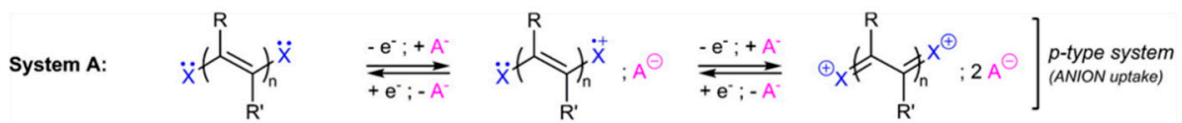

(a)

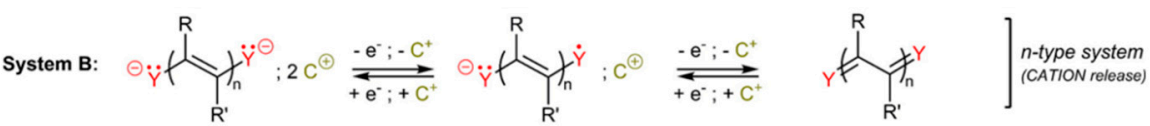

(b)

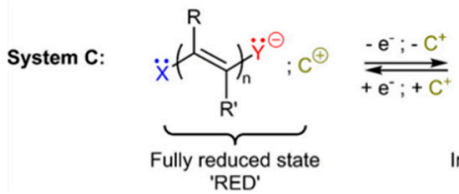

'RED'
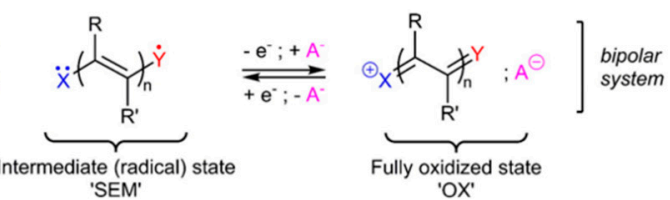

(c)

Figure 6. (a-c) 3 general key redox-active organic systems and their related charge transfer steps (adapted from Hünig's classification [104]).

Quinones are a class of organic compounds that are derived from aromatic compounds by the conversion of an even number of $-\mathrm{CH}=$ groups into $-\mathrm{C}(=\mathrm{O})$ - groups, resulting in a fully conjugated cyclic dione structure (Figure $7 \mathrm{a}$, inset and Figure $7 \mathrm{~b}$, inset). A remarkable result with a naphtoquinone (NQ)-derivative was obtained by adding amino groups at the 2- and 3-positions of the NQ ring to form 2,3-diamino-1,4-naphthoquinone (DANQ) [108]. This material was tested in a cell containing a Li metal counter electrode, in $1 \mathrm{M}$ LiTFSI in $2: 1 \mathrm{v} / \mathrm{v}$ 1,3-dioxolane and dimethoxy-ethane. The initial capacity at a slow rate of $0.2 \mathrm{C}$ was $250 \mathrm{mAh} \mathrm{g}^{-1}\left(363 \mathrm{mAh} \mathrm{cm}^{-3}\right)$. The rate capability was exceptional at $117 \mathrm{mAh} \mathrm{g}^{-1}$ $\left(170 \mathrm{mAh} \mathrm{cm}^{-3}\right)$ and was still retained at $20 \mathrm{C}$. This performance is attributable to the fact that DANQ is highly crystallized and is a semiconductor with a low bandgap of $2.74 \mathrm{eV}$, which increases the conductivity, and a $\mathrm{Li}^{+}$diffusion coefficient in the range of 1-6 $\times 10^{-7} \mathrm{~cm}^{2} \mathrm{~s}^{-1}$. This behavior is in part due to the strong electron-donating amino groups in the 2- and 3- positions of NQ, which significantly destabilize the HOMO energy, thereby decreasing the HOMO-LUMO gap. The high Li diffusion values of DANQ can be attributed to the low bandgap, facilitating fast electron/Li+ transfer in the electrode. The cyclization of amino groups into imidazole yielded $1 \mathrm{H}$-naphtho [2,3-d]imidazole-4,9-dione (IMNQ) which led to enhanced HOMO energy and higher redox potentials compared to DANQ (Figure $7 \mathrm{~b}$ ). 


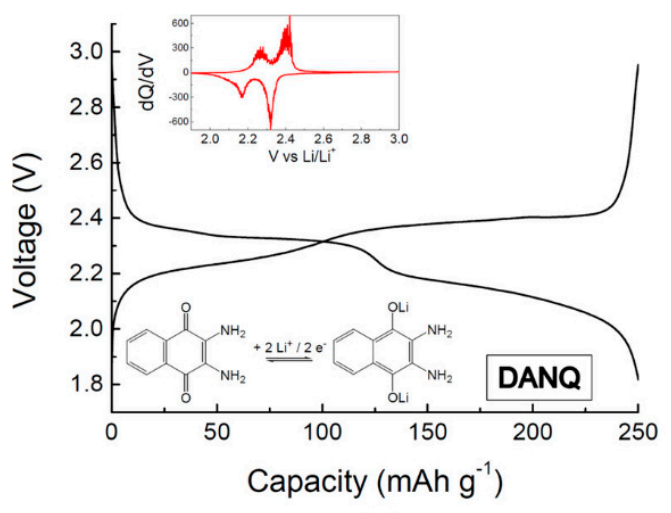

(a)

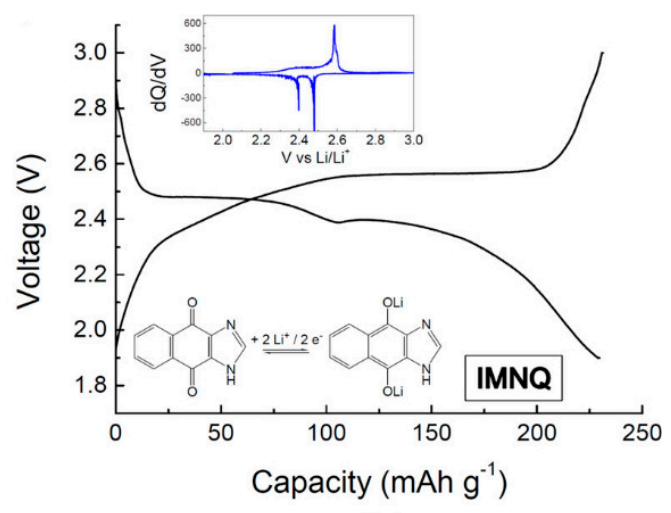

(b)

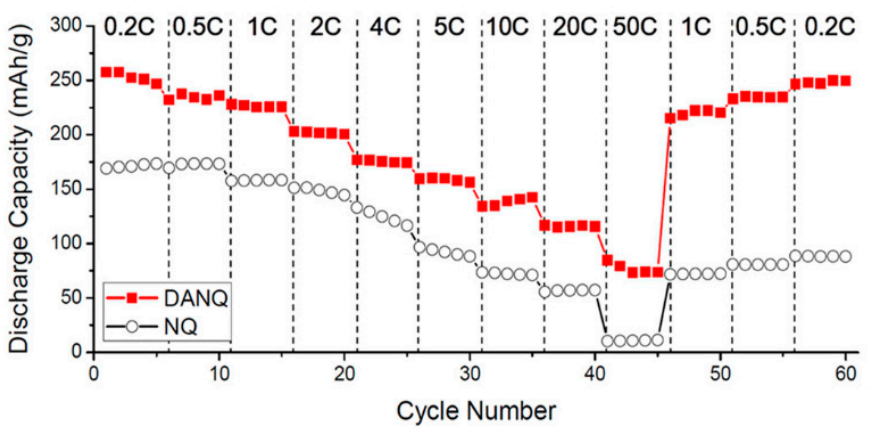

(c)

Figure 7. (a,b) show two-electron electrochemical lithiation and delithiation of 2,3-diamino-1,4naphthoquinone (DANQ) and 1H-naphtho [2,3-d]imidazole-4,9-dione (IMNQ), respectively; (c) rate performance of the Li-DANQ cell compared to Li-NQ cell. Adapted from [108].

Carboxylates are another class of organic material which contain carbonyl groups with a second oxygen atom that is bonded to the carbon atom in the carbonyl group by a single bond. The conjugated dicarboxylates e.g., dilithium terephthalate, dilithium trans-transmuconate, and dilithium 2,6-naphthalene dicarboxylate are studied for potential anodes for Li-ion anodes [105,109]. A remarkable example is dilithium malate due to its small volume effect and unique Li-ion storage mechanism, divided into five steps, as illustrated in Figure 8 [110]. It was tested in a half cell composed of Li metal counter electrode and $1 \mathrm{M} \mathrm{LiPF}_{6}$ in ethylene carbonate:diethyl carbonate:dimethyl carbonate (EC : DEC : DMC, $1: 1: 1$ by $v / v$ ) electrolyte. As Wang et al. explain: "First, two carboxyl hydrogen atoms composed of maleic acid are irreversibly replaced by two lithium ions. Subsequently, a two-electron reduction reaction occurs on the two carbonyl groups. Afterwards, another two-electron reduction occurs. In the fourth step, two-electron reduction continues on the two carbonyl groups. The last step is another two-electron reduction. In all, eight electrons are involved in this scheme, while the experimental value of the capacity, $1500 \mathrm{mAh} \mathrm{g}^{-1}$ at $46.2 \mathrm{~mA} \mathrm{~g}^{-1}$, corresponds to 12 electrons that are involved in the reduction process. The difference was attributed to the surface adsorption of lithium. The rate capability is also astonishing where at $4.62,23.1$, and $46.2 \mathrm{~A} \mathrm{~g}^{-1}$ discharge rate, the electrode is still able to deliver 919.6, 607.2, and 457.2 $\mathrm{mAh}^{-1}$, respectively, which demonstrates the superior performance of the carboxyl-based anode." 


(I)

(a)

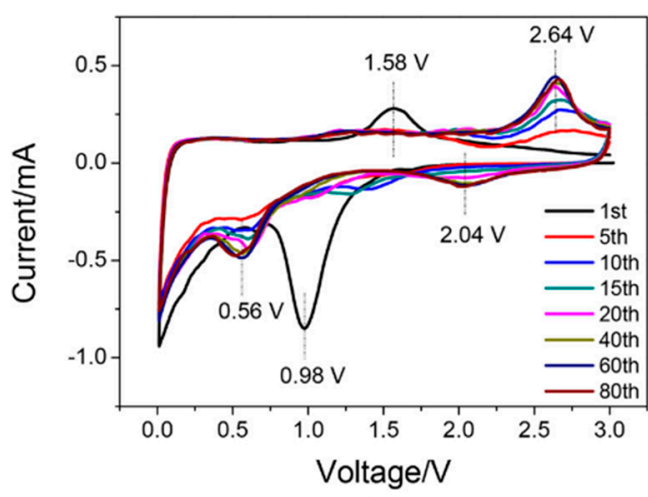

(b)

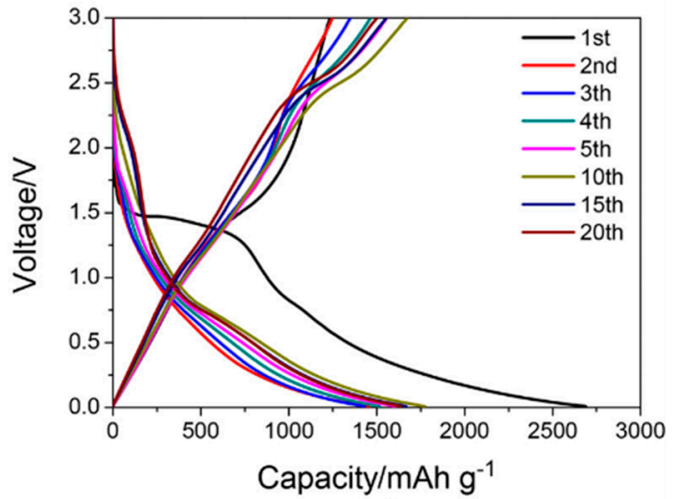

(c)

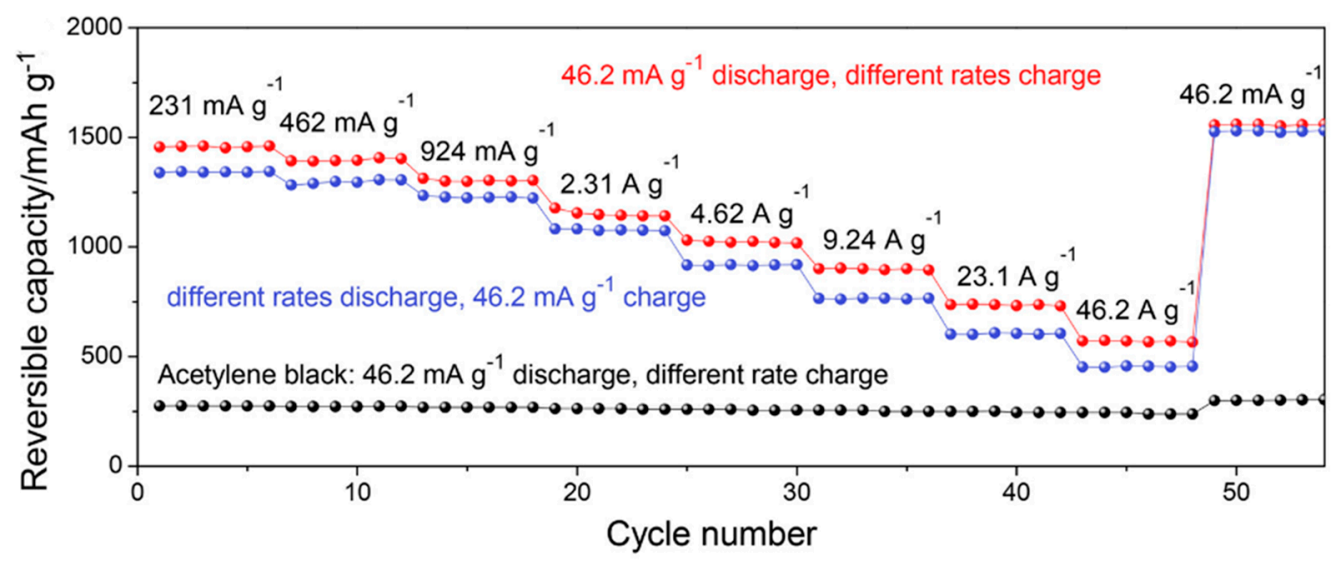

(d)

Figure 8. (a) Structure \& proposed lithiation mechanism of the maleic acid as an anode; (b) cyclic voltammograms and (c) voltage profiles and charge and discharge profiles at $46.2 \mathrm{~mA} \mathrm{~g}^{-1}$ in the voltage range of $0.01-3.0 \mathrm{~V} ;(\mathbf{d})$ rate capability at room temperature (red and blue line correspond to charge and discharge, respectively). Adapted from [110].

In another example, a 2D hexaazatriphenylene-based (HAT) polymer was not only reported as an LIC anode by Troshin et al. but also for sodium and potassium ion capacitors [111]. The HAT-based polymers are less specific to the nature of the cation, which facil- 
itates the diversification to other alternatives to the currently dominating lithium chemistry. They achieved a specific capacity of $99 \mathrm{mAh} \mathrm{g}^{-1}$ using LiTFSI in dimethoxyethane (DME) as an electrolyte at a very high current density of $10 \mathrm{~A} \mathrm{~g}^{-1}$ (i.e., charging/discharging in ca. $1 \mathrm{~min}$ ) after 1000 cycles with $82 \%$ capacity retention. The performance was better in the case of sodium and potassium. For sodium cells, a capacity of $117 \mathrm{mAh} \mathrm{g}^{-1}$ at high current density of $10 \mathrm{~A} \mathrm{~g}^{-1}$ (which is equivalent to $85 \mathrm{C}$ current rate) after 1950 cycles. As for potassium cells, they reported a specific capacity of $169 \mathrm{~mA} \mathrm{~h} \mathrm{~g}^{-1}$ at current density of $10 \mathrm{~A} \mathrm{~g}^{-1}$ after 4600 cycles. The long cycle life and stability of the electrodes are a result of the supramolecular structure of the polymer, which mitigated the dissolution of the organic electrode in the electrolyte while enhancing the ionic conductivity in the electrode structure.

In essence, organic-based electrodes are a very promising class of materials for energystorage devices due to reasons discussed above; however, they are not commercially ready yet. This is due to their reactivity and solubility in the electrolytes-if they are based on single molecules, large molecular size, and high redox potentials as anodes, which in turn result in short cycle life, low energy density and specific energy, respectively. Also, the stability of lithium-containing organic materials in air is a major hurdle. Nonetheless, the potential of organic electrodes is yet to be realized as there is a great scientific and technological interest in doing so. Organic chemistry is versatile and can allow for the tuning of the voltage, solubility, and the reaction kinetics of such materials by careful engineering of chemical functionalities. Also, albeit the capacitive behavior of such organic materials, especially on the anode side as illustrated in Figure 8b, they are not entirely denoted as LIC electrodes. For example, in some work they are referred to as "Fast Charging Electrodes" [111]. This might be due to the infancy of the organic electrodes and the lack of a clear definition of their role in the energy storage field.

\section{Emerging Materials}

While the present review is focused on the materials which are industrially relevant and could soon be applied in commercial devices, one class of materials is on the rise and could become commercially viable in the near future: two-dimensional materials. Recently, the discovery of two-dimensional materials initiated wide deployment of these materials in energy storage devices. 2D materials demonstrated remarkable conductivity and deliver ionic transport while delivering high surface area. The first ever reported 2D material, graphene, demonstrated an incredible surface-to-mass ratio of $\sim 2600 \mathrm{~m}^{2} \mathrm{~g}^{-1}$ [112]. Such remarkable properties (high surface area combined with high conductivity) made them materials of choice for supercapacitors [113], and therefore, for LICs as well. Various 2D materials have been evaluated for their electrochemical activity, which includes graphenebased materials, transition metal chalcogenides and transition metal carbides, nitrides and carbonitrides (MXenes) [114,115].

The rapid development of the area of 2D materials and demonstration of their applicability quickly resulted in evaluation of these materials in LICs. Among these materials, MXenes are viewed as particularly promising $[116,117]$. MXenes are of the class of materials with a general formula of $\mathrm{M}_{\mathrm{n}+1} \mathrm{X}_{\mathrm{n}} \mathrm{T}_{\mathrm{x}}\left(\mathrm{M}=\mathrm{Ti}, \mathrm{Zr}, \mathrm{V}, \mathrm{Nb}, \mathrm{Cr}, \mathrm{Mo}\right.$, etc.; $\mathrm{X}=\mathrm{C}, \mathrm{N} ; \mathrm{T}_{\mathrm{x}}=\mathrm{F}$, $\mathrm{OH}, \mathrm{O}, \mathrm{Cl}$, etc.; $\mathrm{n}=1 \sim 3$ ), where Ti-based materials are the most mature, popular and attractive [118]. Those are also the most likely candidates for commercialization. The initial synthesis of MXenes involves the use of concentrated HF to remove $\mathrm{Al}$ in the $\mathrm{M}_{n+1} \mathrm{AlX}_{\mathrm{n}}$ structure [119]. However, later work conducted by Gogotsi et al. proposed more appealing synthetic alternatives not involving the direct use of HF [120,121]. Such routes may potentially open the possibilities for scalable preparation of these promising materials.

An example of such application is a demonstration of titanium carbide $\left(\mathrm{Ti}_{3} \mathrm{C}_{2} \mathrm{~T}_{\mathrm{x}}\right)$ combined with carbon nanotubes (CNT) [122]. This combination allowed the fabrication of binder-free composites which were cycled against activated carbon using $1 \mathrm{M} \mathrm{LiPF}_{6}$ in a mixture of ethylene carbonate (EC)/diethyl carbonate (DEC)/dimethyl carbonate (DMC) at a volume ratio of $1: 1: 1$. Prior to device fabrication, an electrochemical prelithiation of the composite was performed. At a power density of $258 \mathrm{~W} \mathrm{~kg}^{-1}$, the $\mathrm{Ti}_{3} \mathrm{C}_{2} \mathrm{~T}_{\mathrm{x}} / \mathrm{CNT} / / \mathrm{AC}$ 
lithium-ion capacitor can achieve a high energy density of $67 \mathrm{Wh} \mathrm{kg}^{-1}$, based on the weights of active materials $\mathrm{Ti}_{3} \mathrm{C}_{2} \mathrm{~T}_{\mathrm{x}} / \mathrm{CNTs}$ and $\mathrm{AC}$. When the power density increases to $5797 \mathrm{~W} \mathrm{~kg}^{-1}$, the $\mathrm{Ti}_{3} \mathrm{C}_{2} \mathrm{~T}_{\mathrm{x}} / \mathrm{CNT} / / \mathrm{AC}$ corresponding LIC device can deliver $19 \mathrm{Wh} \mathrm{kg}^{-1}$. Furthermore, the $\mathrm{Ti}_{3} \mathrm{C}_{2} \mathrm{~T}_{\mathrm{x}} / \mathrm{CNTs} / / \mathrm{AC}$ LIC exhibits good cycling with a capacity retention of $81.3 \%$ after 5000 cycles at the current density of $2 \mathrm{~A} \mathrm{~g}^{-1}$, and the Coulombic efficiency is nearly $100 \%$ during the cycling test.

While these materials represent great promise for the growing LIC technology, they still need to be viewed as an emerging generation of LIC materials. The complexity of their preparation and scalability, as a result, raise a major concern which is yet to be solved. Therefore, while the new materials concepts are on the horizon, they would need to be revised for pragmatic implementation.

\section{Conclusions and Future Prospects}

Despite the great promise of the materials described in the present review, the majority are yet to be evaluated in industrially relevant prototypes. However, for practical application, it is important to compare these materials back-to-back. It is important to note that the differences in reporting (as discussed in Section 2) make the comparison more complicated than the relevant industries would prefer. As mentioned above, the majority of published results are compared to their alternatives through Ragone plots, which only allows a general mapping of the proposed chemistry/approach and can serve only as a general guideline. Thus, for an accurate comparison of the potential materials, the following key performance indicators (KPIs) need to be considered. Such KPIs for the most popular materials which are expected to be commercialized in the nearest future are listed in Table 1.

Table 1. Key performance indicators (KPIs) for the materials with the highest manufacturing potential for negative electrodes of LICs. Cycle life values are only examples as values in the field vary substantially and depend on many other factors.

\begin{tabular}{|c|c|c|c|c|c|}
\hline Material $^{1}$ & $\begin{array}{l}\text { Operating Potential } \\
\quad\left(\mathrm{V} \text { vs. } \mathrm{Li} / \mathrm{Li}^{+}\right)\end{array}$ & $\begin{array}{c}\text { Theoretical } \\
\text { Capacity }\left(\mathrm{mAh} \mathrm{g}^{-1}\right)\end{array}$ & Cycle Life & $\begin{array}{c}\text { Relative } \\
\text { Abundance } 1\end{array}$ & $\begin{array}{c}\text { Relative } \\
\text { Affordability }^{2}\end{array}$ \\
\hline $\mathrm{TiO}_{2}$ polymorphs & 1.55 [19] & 335 [123] & $10,000[32]$ & High & High \\
\hline $\mathrm{Nb}_{2} \mathrm{O}_{5}$ & $1.7[124]$ & 190 [124] & $3000[51]$ & Moderate & Moderate \\
\hline TNO & $1.64[125]$ & $388-397$ [55] & $500[57]$ & Moderate & Moderate \\
\hline Si (LIC) & $0.4[73]$ & $3579[73]$ & 800 [81] & Very high & Very high $^{3}$ \\
\hline
\end{tabular}

${ }^{1}$ Relative abundance ranks are estimated according to abundance in the Earth's crust. ${ }^{2}$ Relative affordability ranks are based on the authors' estimates of bulk raw materials. ${ }^{3}$ Bulk $\mathrm{Si}$ is highly affordable while nanoparticulate $\mathrm{Si}$ is substantially less so.

Furthermore, the authors believe that in addition to the Ragone plot for graphical representation of potential approaches, the advancements in materials for LICs are better represented by the spider diagram which accounts for all KPIs described above. Therefore, such a diagram for the most promising materials $\left(\mathrm{TiO}_{2}, \mathrm{Nb}_{2} \mathrm{O}_{5}, \mathrm{TNO}\right.$ and $\left.\mathrm{Si}\right)$ is shown below in Figure 9.

Another major drawback for LICs is the prelithiation step discussed above-a step that is still under development and which complicates the manufacturing of the LICs. The scalability of prelithiation is currently a significant barrier to deployment of the technology. Currently, four major pathways to prelithiation exist (electrochemical, short circuit, stabilized Li metal powder, and chemical), each with their own drawbacks, but implementation at large scale is pragmatically only viable if performed in situ. Notably however, recent advances in this direction may lift the restrictions. Furthermore, the development of the materials which do not require prelithiation is encouraging and is viewed by the authors as a next step for the development of LIC technology.

In conclusion, over the past few years LICs have demonstrated an astonishing growth beyond the research laboratories and have also created substantial industrial momentum. Benefiting from the balance of energy and power described above, LIC technology is currently viewed as an energy-storage solution for grid stabilization. 


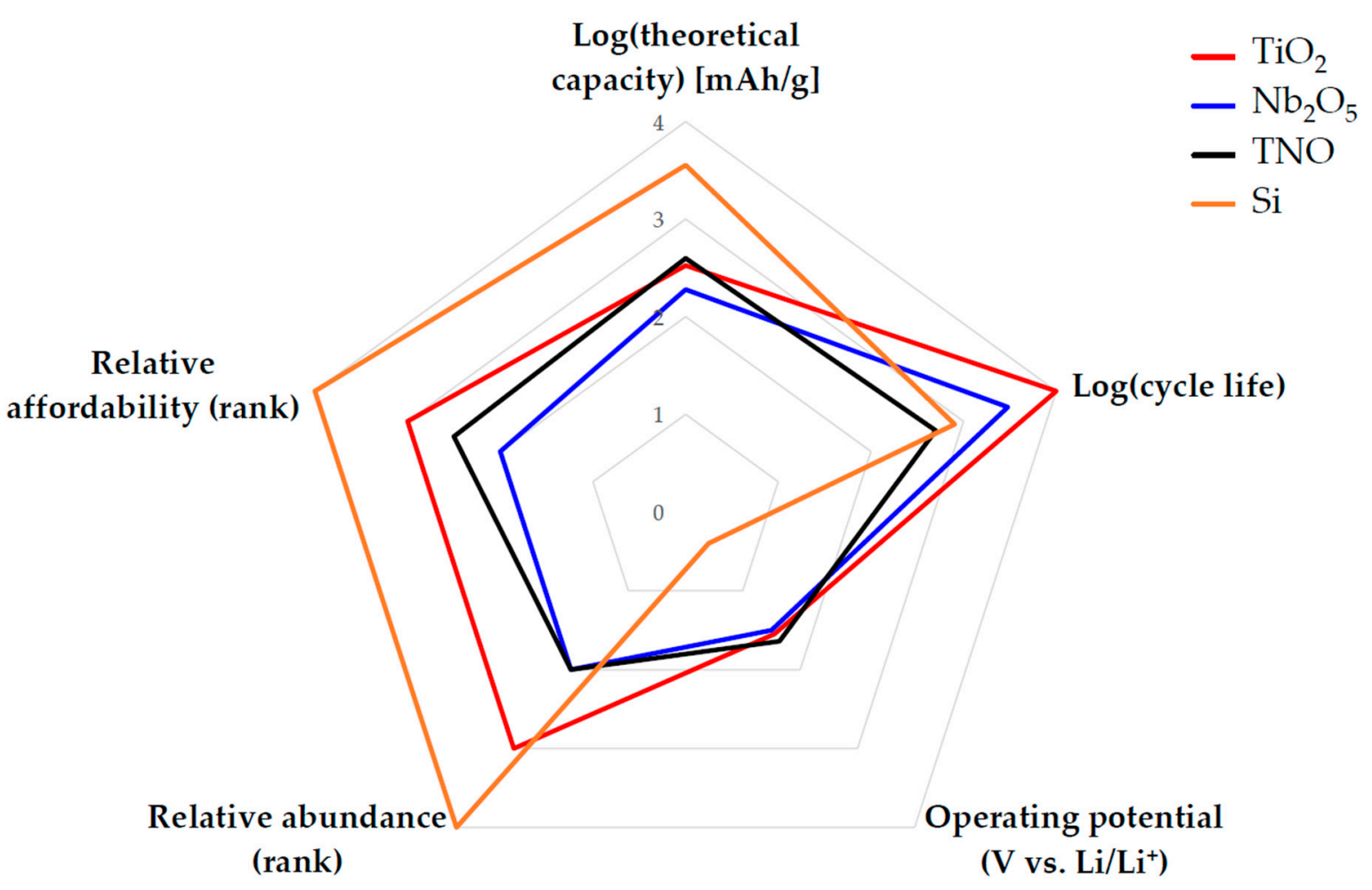

Figure 9. A "spider web" or "radar" chart can comparatively evaluate the complex performance-determining parameters of different materials with greater detail than a Ragone plot. Cycle life and theoretical capacity are plotted on a log scale for clarity. For ranked parameters, higher values indicate higher rank (e.g., Si is relatively the most abundant material of the four selected here).

Author Contributions: Conceptualization, S.Y.L. and A.Y.K.; formal analysis, C.C., M.E.A., S.Y.L. and A.Y.K.; writing-original draft preparation, C.C., M.E.A., S.Y.L., F.L. and A.Y.K.; writingreview and editing, C.C., M.E.A., S.Y.L. and A.Y.K.; visualization, M.E.A.; supervision, A.Y.K.; funding acquisition, S.Y.L. and A.Y.K. All authors have read and agreed to the published version of the manuscript.

Funding: This research was funded by the Research Council of Norway under grant number 309721. This work was performed within MoZEES, a Norwegian Centre for Environment-friendly Energy Research (FME), co-sponsored by the Research Council of Norway (project number 257653) and 40 partners from research, industry and public sector.

Acknowledgments: The authors thank Giulio Calcagno (Chalmers University of Technology) for helpful discussions of the Ragone plot.

Conflicts of Interest: The authors declare no conflict of interest. The funders had no role in the design of the study; in the collection, analyses, or interpretation of data; in the writing of the manuscript; or in the decision to publish the results.

\section{References}

1. Morton, S.; Pencheon, D.; Squires, N. Sustainable Development Goals (SDGs), and Their Implementation: A National Global Framework for Health, Development and Equity Needs a Systems Approach at Every Level. Br. Med Bull. 2017, 124, 81-90. [CrossRef] [PubMed]

2. Gür, T.M. Review of Electrical Energy Storage Technologies, Materials and Systems: Challenges and Prospects for Large-scale Grid Storage. Energy Environ. Sci. 2018, 11, 2696-2767. [CrossRef]

3. Kyriakopoulos, G.L.; Arabatzis, G. Electrical Energy Storage Systems in Electricity Generation: Energy Policies, Innovative Technologies, and Regulatory Regimes. Renew. Sustain. Energy Rev. 2016, 56, 1044-1067. [CrossRef]

4. The Nobel Prize in Chemistry 2019. Available online: NobelPrize.org (accessed on 21 May 2021).

5. Tarascon, J.M.; Armand, M. Issues and Challenges Facing Rechargeable Lithium Batteries. Nature 2001, 414, 359-367. [CrossRef] [PubMed] 
6. Simon, P.; Gogotsi, Y.; Dunn, B. Where Do Batteries End and Supercapacitors Begin? Science 2014, 343, 1210-1211. [CrossRef]

7. Dubal, D.P.; Ayyad, O.; Ruiz, V.; Gómez-Romero, P. Hybrid Energy Storage: The Merging of Battery and Supercapacitor Chemistries. Chem. Soc. Rev. 2015, 44, 1777-1790. [CrossRef] [PubMed]

8. Afif, A.; Rahman, S.M.H.; Tasfiah Azad, A.; Zaini, J.; Islan, M.A.; Azad, A.K. Advanced Materials and Technologies for Hybrid Supercapacitors for Energy Storage-A Review. J. Energy Storage 2019, 25, 100852. [CrossRef]

9. Bocklisch, T. Hybrid Energy Storage Systems for Renewable Energy Applications. Energy Procedia 2015, 73, 103-111. [CrossRef]

10. Shao, Y.; El-Kady, M.F.; Sun, J.; Li, Y.; Zhang, Q.; Zhu, M.; Wang, H.; Dunn, B.; Kaner, R.B. Design and Mechanisms of Asymmetric Supercapacitors. Chem. Rev. 2018, 118, 9233-9280. [CrossRef]

11. Chen, G.Z. Supercapacitor and Supercapattery as Emerging Electrochemical Energy Stores. Int. Mater. Rev. 2017, 62, 173-202. [CrossRef]

12. Ding, J.; Hu, W.; Paek, E.; Mitlin, D. Review of Hybrid Ion Capacitors: From Aqueous to Lithium to Sodium. Chem. Rev. 2018, 118, 6457-6498. [CrossRef] [PubMed]

13. Wang, X.; Liu, L.; Niu, Z. Carbon-based Materials for Lithium-ion Capacitors. Mater. Chem. Front. 2019, 3, 1265-1279. [CrossRef]

14. Soltani, M.; Beheshti, S.H. A Comprehensive Review of Lithium Ion Capacitor: Development, Modelling, Thermal Management and Applications. J. Energy Storage 2020. [CrossRef]

15. Aravindan, V.; Gnanaraj, J.; Lee, Y.-S.; Madhavi, S. Insertion-Type Electrodes for Nonaqueous Li-Ion Capacitors. Chem. Rev. 2014, 114, 11619-11635. [CrossRef] [PubMed]

16. Wang, H.; Zhu, C.; Chao, D.; Yan, Q.; Fan, H.J. Nonaqueous Hybrid Lithium-Ion and Sodium-Ion Capacitors. Adv. Mater. 2017, 29, 1702093. [CrossRef]

17. Han, C.; Li, H.; Shi, R.; Xu, L.; Li, J.; Kang, F.; Li, B. Nanostructured Anode Materials for Non-aqueous Lithium Ion Hybrid Capacitors. Energy Environ. Mater. 2018, 1, 75-87. [CrossRef]

18. Han, P.; Xu, G.; Han, X.; Zhao, J.; Zhou, X.; Cui, G. Lithium Ion Capacitors in Organic Electrolyte System: Scientific Problems, Material Development, and Key Technologies. Adv. Energy Mater. 2018, 8, 1801243. [CrossRef]

19. Jagadale, A.; Zhou, X.; Xiong, R.; Dubal, D.P.; Xu, J.; Yang, S. Lithium Ion Capacitors (LICs): Development of the Materials. Energy Storage Mater. 2019, 19, 314-329. [CrossRef]

20. Kim, B.K.; Sy, S.; Yu, A.; Zhang, J. Electrochemical Supercapacitors for Energy Storage and Conversion. In Handbook of Clean Energy Systems; John Wiley \& Sons: New York, NY, USA, 2015; pp. 1-25.

21. Aravindan, V.; Lee, Y.-S. Building Next-Generation Li-ion Capacitors with High Energy: An Approach beyond Intercalation. J. Phys. Chem. Lett. 2018, 9, 3946-3958. [CrossRef]

22. Li, B.; Zheng, J.; Zhang, H.; Jin, L.; Yang, D.; Lv, H.; Shen, C.; Shellikeri, A.; Zheng, Y.; Gong, R.; et al. Electrode Materials, Electrolytes, and Challenges in Nonaqueous Lithium-Ion Capacitors. Adv. Mater. 2018, 30, 1705670. [CrossRef]

23. Winter, M.; Brodd, R.J. What Are Batteries, Fuel Cells, and Supercapacitors? Chem. Rev. 2004, 104, 4245-4270. [CrossRef]

24. Christen, T. Ragone Plots and Discharge Efficiency-power Relations of Electric and Thermal Energy Storage Devices. J. Energy Storage 2020, 27, 101084. [CrossRef]

25. Arbizzani, C.; Yu, Y.; Li, J.; Xiao, J.; Xia, Y.-y.; Yang, Y.; Santato, C.; Raccichini, R.; Passerini, S. Good Practice Guide for Papers on Supercapacitors and Related Hybrid Capacitors for the Journal of Power Sources. J. Power Sources 2020, 450, 227636. [CrossRef]

26. Li, J.; Arbizzani, C.; Kjelstrup, S.; Xiao, J.; Xia, Y.-y.; Yu, Y.; Yang, Y.; Belharouak, I.; Zawodzinski, T.; Myung, S.-T.; et al. Good Practice Guide for Papers on Batteries for the Journal of Power Sources. J. Power Sources 2020, 452, 227824. [CrossRef]

27. Jin, L.; Shen, C.; Shellikeri, A.; Wu, Q.; Zheng, J.; Andrei, P.; Zhang, J.-G.; Zheng, J.P. Progress and Perspectives on Pre-lithiation Technologies for Lithium Ion Capacitors. Energy Environ. Sci. 2020, 13, 2341-2362. [CrossRef]

28. Wang, F.; Wang, B.; Li, J.; Wang, B.; Zhou, Y.; Wang, D.; Liu, H.; Dou, S. Prelithiation: A Crucial Strategy for Boosting the Practical Application of Next-Generation Lithium Ion Battery. ACS Nano 2021, 15, 2197-2218. [CrossRef]

29. Sun, X.; Zhang, X.; Zhang, H.; Xu, N.; Wang, K.; Ma, Y. High Performance Lithium-ion Hybrid Capacitors with Pre-lithiated Hard Carbon Anodes and Bifunctional Cathode Electrodes. J. Power Sources 2014, 270, 318-325. [CrossRef]

30. Jang, J.; Kang, I.; Choi, J.; Jeong, H.; Yi, K.-W.; Hong, J.; Lee, M. Molecularly Tailored Lithium-Arene Complex Enables Chemical Prelithiation of High-Capacity Lithium-Ion Battery Anodes. Angew. Chem. Int. Ed. 2020, 59, 14473-14480. [CrossRef]

31. An, C.; Zhang, Y.; Guo, H.; Wang, Y. Metal Oxide-based Supercapacitors: Progress and Prospectives. Nanoscale Adv. 2019, 1, 4644-4658. [CrossRef]

32. Calcagno, G.; Lotsari, A.; Matic, A.; Lindberg, S.; Cavallo, C. Fast Charging Negative Electrodes Based on Anatase Titanium Dioxide Beads for Highly Stable Li-ion Capacitors. Mater. Today Energy 2020, 16, 100424. [CrossRef]

33. Lu, X.; Zhao, L.; He, X.; Xiao, R.; Gu, L.; Hu, Y.-S.; Li, H.; Wang, Z.; Duan, X.; Chen, L.; et al. Lithium Storage in $\mathrm{Li}_{4} \mathrm{Ti}_{5} \mathrm{O}_{12} \mathrm{Spinel}$ The Full Static Picture from Electron Microscopy. Adv. Mater. 2012, 24, 3233-3238. [CrossRef] [PubMed]

34. Liang, X.; Qi, R.; Zhao, M.; Zhang, Z.; Liu, M.; Pu, X.; Wang, Z.L.; Lu, X. Ultrafast Lithium-ion Capacitors for Efficient Storage of Energy Generated by Triboelectric Nanogenerators. Energy Storage Mater. 2020, 24, 297-303. [CrossRef]

35. Zhao, E.; Qin, C.; Jung, H.-R.; Berdichevsky, G.; Nese, A.; Marder, S.; Yushin, G. Lithium Titanate Confined in Carbon Nanopores for Asymmetric Supercapacitors. ACS Nano 2016, 10, 3977-3984. [CrossRef] [PubMed]

36. Chen, S.; Xin, Y.; Zhou, Y.; Ma, Y.; Zhou, H.; Qi, L. Self-supported $\mathrm{Li}_{4} \mathrm{Ti}_{5} \mathrm{O}_{12}$ Nanosheet Arrays for Lithium Ion Batteries with Excellent Rate Capability and Ultralong Cycle Life. Energy Environ. Sci. 2014, 7, 1924-1930. [CrossRef] 
37. Jeong, J.H.; Kim, M.-S.; Choi, Y.J.; Lee, G.-W.; Park, B.H.; Lee, S.-W.; Roh, K.C.; Kim, K.-B. Rational Design of Oxide/Carbon Composites to Achieve Superior Rate-capability via Enhanced Lithium-ion Transport Across Carbon to Oxide. J. Mater. Chem. A 2018, 6, 6033-6044. [CrossRef]

38. Zhou, C.-a.; Xia, X.; Wang, Y.; Yao, Z.; Wu, J.; Wang, X.; Tu, J. Pine-Needle-Like Cu-Co Skeleton Composited with $\mathrm{Li}_{4} \mathrm{Ti}_{5} \mathrm{O}_{12}$ Forming Core-Branch Arrays for High-Rate Lithium Ion Storage. Small 2018, 14, 1704339. [CrossRef]

39. Zhou, C.-a.; Xia, X.; Wang, Y.; Zhong, Y.; Yao, Z.; Wang, X.; Tu, J. Rational Construction of a Metal Core for Smart Combination with $\mathrm{Li}_{4} \mathrm{Ti}_{5} \mathrm{O}_{12}$ as Integrated Arrays with Superior High-rate Li-ion Storage Performance. J. Mater. Chem. A 2017, 5, 1394-1399. [CrossRef]

40. Wang, G.; Lu, C.; Zhang, X.; Wan, B.; Liu, H.; Xia, M.; Gou, H.; Xin, G.; Lian, J.; Zhang, Y. Toward Ultrafast Lithium Ion Capacitors: A Novel Atomic Layer Deposition Seeded Preparation of $\mathrm{Li}_{4} \mathrm{Ti}_{5} \mathrm{O}_{12} /$ Graphene Anode. Nano Energy 2017, 36, 46-57. [CrossRef]

41. Que, L.-F.; Yu, F.-D.; Wang, Z.-B.; Gu, D.-M. Pseudocapacitance of $\mathrm{TiO}_{2-\mathrm{x}} / \mathrm{CNT}$ Anodes for High-Performance Quasi-Solid-State Li-Ion and Na-Ion Capacitors. Small 2018, 14, 1704508. [CrossRef]

42. Tian, Y.; Xu, G.; Wu, Z.; Zhong, J.; Yang, L. Dual-phase Spinel $\mathrm{Li}_{4} \mathrm{Ti}_{5} \mathrm{O}_{12} /$ Anatase $\mathrm{TiO}_{2}$ Nanosheet Anchored 3D Reduced Graphene Oxide Aerogel Scaffolds as Self-supporting Electrodes for High-performance Na- and Li-ion Batteries. RSC Adv. 2017, 7, 52702-52711. [CrossRef]

43. Zhu, W.; Yang, H.; Zhang, W.; Huang, H.; Tao, X.; Xia, Y.; Gan, Y.; Guo, X. Synthesis and Electrochemical Performance of $\mathrm{Li}_{4} \mathrm{Ti}_{5} \mathrm{O}_{12} / \mathrm{TiO}_{2} / \mathrm{C}$ Nanocrystallines for High-rate Lithium Ion Batteries. RSC Adv. 2015, 5, 74774-74782. [CrossRef]

44. Zhou, H.; Ma, Q.; Yang, W.; Lu, X. $\mathrm{Li}_{4} \mathrm{Ti}_{5} \mathrm{O}_{12}-\mathrm{TiO}_{2}$ Composite Coated on Carbon Foam as Anode Material for Lithium Ion Capacitors: Evaluation of Rate Performance and Self-Discharge. ChemNanoMat 2020, 6, 280-284. [CrossRef]

45. Liu, Z.; Dong, W.; Wang, J.; Dong, C.; Lin, Y.; Chen, I.W.; Huang, F. Orthorhombic $\mathrm{Nb}_{2} \mathrm{O}_{5-\mathrm{x}}$ for Durable High-Rate Anode of Li-Ion Batteries. iScience 2020, 23, 100767. [CrossRef]

46. Augustyn, V.; Come, J.; Lowe, M.A.; Kim, J.W.; Taberna, P.-L.; Tolbert, S.H.; Abruña, H.D.; Simon, P.; Dunn, B. High-rate Electrochemical Energy Storage through Li+ Intercalation Pseudocapacitance. Nat. Mater. 2013, 12, 518-522. [CrossRef]

47. Kim, J.W.; Augustyn, V.; Dunn, B. The Effect of Crystallinity on the Rapid Pseudocapacitive Response of $\mathrm{Nb}_{2} \mathrm{O}_{5}$. Adv. Energy Mater. 2012, 2, 141-148. [CrossRef]

48. Kong, L.; Zhang, C.; Wang, J.; Qiao, W.; Ling, L.; Long, D. Free-Standing T- $-\mathrm{Nb}_{2} \mathrm{O}_{5}$ /Graphene Composite Papers with Ultrahigh Gravimetric/Volumetric Capacitance for Li-Ion Intercalation Pseudocapacitor. ACS Nano 2015, 9, 11200-11208. [CrossRef]

49. Sun, H.; Mei, L.; Liang, J.; Zhao, Z.; Lee, C.; Fei, H.; Ding, M.; Lau, J.; Li, M.; Wang, C.; et al. Three-dimensional Holeygraphene/Niobia Composite Architectures for Ultrahigh-rate Energy Storage. Science 2017, 356, 599-604. [CrossRef] [PubMed]

50. Liu, S.; Zhou, J.; Cai, Z.; Fang, G.; Cai, Y.; Pan, A.; Liang, S. $\mathrm{Nb}_{2} \mathrm{O}_{5}$ Quantum Dots Embedded in MOF Derived Nitrogen-doped Porous Carbon for Advanced Hybrid Supercapacitor Applications. J. Mater. Chem. A 2016, 4, 17838-17847. [CrossRef]

51. Li, H.; Li, D.; Shi, J.; He, Z.; Zhao, Z.; Wang, H. Carbon Coated 3D Nb $2 \mathrm{O}_{5}$ Hollow Nanospheres with Superior Performance as an Anode for High Energy Li-ion Capacitors. Sustain. Energy Fuels 2020, 4, 4868-4877. [CrossRef]

52. Qin, L.; Liu, Y.; Xu, S.; Wang, S.; Sun, X.; Zhu, S.; Hou, L.; Yuan, C. In-Plane Assembled Single-Crystalline T-Nb ${ }_{2} \mathrm{O}_{5} \mathrm{Nanorods}$ Derived from Few-Layered $\mathrm{Nb}_{2} \mathrm{CT}_{\mathrm{x}}$ MXene Nanosheets for Advanced Li-Ion Capacitors. Small Methods 2020, 4, 2000630. [CrossRef]

53. Yuan, T.; Soule, L.; Zhao, B.; Zou, J.; Yang, J.; Liu, M.; Zheng, S. Recent Advances in Titanium Niobium Oxide Anodes for High-Power Lithium-Ion Batteries. Energy Fuels 2020, 34, 13321-13334. [CrossRef]

54. Han, J.-T.; Huang, Y.-H.; Goodenough, J.B. New Anode Framework for Rechargeable Lithium Batteries. Chem. Mater. 2011, 23, 2027-2029. [CrossRef]

55. Yu, H.; Cheng, X.; Zhu, H.; Zheng, R.; Liu, T.; Zhang, J.; Shui, M.; Xie, Y.; Shu, J. Deep Insights into Kinetics and Structural Evolution of Nitrogen-doped Carbon Coated $\mathrm{TiNb}_{24} \mathrm{O}_{62}$ Nanowires as High-performance Lithium Container. Nano Energy 2018, 54, 227-237. [CrossRef]

56. Yuan, T.; Luo, S.; Soule, L.; Wang, J.-H.; Wang, Y.; Sun, D.; Zhao, B.; Li, W.; Yang, J.; Zheng, S.; et al. A Hierarchical Ti $2 \mathrm{Nb}_{10} \mathrm{O}_{29}$ Composite Electrode for High-power Lithium-ion Batteries and Capacitors. Mater. Today 2021. [CrossRef]

57. Budak, Ö.; Srimuk, P.; Aslan, M.; Shim, H.; Borchardt, L.; Presser, V. Titanium Niobium Oxide $\mathrm{Ti}_{2} \mathrm{Nb}_{10} \mathrm{O}_{29} / \mathrm{Carbon}_{\mathrm{Hyb}} \mathrm{Hid}$ Electrodes Derived by Mechanochemically Synthesized Carbide for High-Performance Lithium-Ion Batteries. ChemSusChem 2021, 14, 398-407. [CrossRef] [PubMed]

58. Yang, M.; Zhong, Y.; Ren, J.; Zhou, X.; Wei, J.; Zhou, Z. Fabrication of High-Power Li-Ion Hybrid Supercapacitors by Enhancing the Exterior Surface Charge Storage. Adv. Energy Mater. 2015, 5, 1500550. [CrossRef]

59. Zhao, X.; Wang, H.-E.; Cao, J.; Cai, W.; Sui, J. Amorphous/Crystalline Hybrid $\mathrm{MoO}_{2}$ Nanosheets for High-energy Lithium-ion Capacitors. Chem. Commun. 2017, 53, 10723-10726. [CrossRef] [PubMed]

60. Shi, R.; Han, C.; Xu, X.; Qin, X.; Xu, L.; Li, H.; Li, J.; Wong, C.-P.; Li, B. Electrospun N-Doped Hierarchical Porous Carbon Nanofiber with Improved Degree of Graphitization for High-Performance Lithium Ion Capacitor. Chem. Eur. J. 2018, 24, 10460-10467. [CrossRef]

61. Brandt, A.; Balducci, A. A Study about the Use of Carbon Coated Iron Oxide-based Electrodes in Lithium-ion Capacitors. Electrochim. Acta 2013, 108, 219-225. [CrossRef]

62. Zhan, Y.; Edison, E.; Manalastas, W.; Tan, M.R.J.; Satish, R.; Buffa, A.; Madhavi, S.; Mandler, D. Electrochemical Deposition of Highly Porous Reduced Graphene Oxide Electrodes for Li-ion Capacitors. Electrochim. Acta 2020, 337, 135861. [CrossRef] 
63. Yu, F.; Pang, L.; Wang, H.-X. Preparation of Mulberry-like $\mathrm{RuO}_{2}$ Electrode Material for Supercapacitors. Rare Met. 2020. [CrossRef]

64. Xu, L.; Liu, W.; Hu, Y.; Luo, L. Stress-resilient Electrode Materials for Lithium-ion Batteries: Strategies and Mechanisms. Chem. Commun. 2020, 56, 13301-13312. [CrossRef]

65. Durmus, Y.E.; Zhang, H.; Baakes, F.; Desmaizieres, G.; Hayun, H.; Yang, L.; Kolek, M.; Küpers, V.; Janek, J.; Mandler, D.; et al. Side by Side Battery Technologies with Lithium-Ion Based Batteries. Adv. Energy Mater. 2020, 10, 2000089. [CrossRef]

66. Qi, J.; Zhu, Y.; Zhang, J.; Wang, C. Mulberry-Like Core-Shell Structured C@MnO 2 as Electrode Material for Li-Ion Batteries and Pseudo-Capacitors. ChemistrySelect 2020, 5, 5657-5664. [CrossRef]

67. Huang, L.; Chen, D.; Ding, Y.; Feng, S.; Wang, Z.L.; Liu, M. Nickel-Cobalt Hydroxide Nanosheets Coated on $\mathrm{NiCo}_{2} \mathrm{O}_{4} \mathrm{Nanowires}$ Grown on Carbon Fiber Paper for High-Performance Pseudocapacitors. Nano Lett. 2013, 13, 3135-3139. [CrossRef]

68. Li, S.; Chen, J.; Cui, M.; Cai, G.; Wang, J.; Cui, P.; Gong, X.; Lee, P.S. Capacitors: A High-Performance Lithium-Ion Capacitor Based on 2D Nanosheet Materials (Small 6/2017). Small 2017, 13. [CrossRef]

69. Lee, W.S.V.; Peng, E.; Li, M.; Huang, X.; Xue, J.M. Rational Design of Stable 4V Lithium Ion Capacitor. Nano Energy 2016, 27, 202-212. [CrossRef]

70. Chen, S.; Xue, M.; Li, Y.; Pan, Y.; Zhu, L.; Qiu, S. Rational Design and Synthesis of $\mathrm{Ni}_{\mathrm{x}} \mathrm{Co}_{3-\mathrm{x}} \mathrm{O}_{4}$ Nanoparticles Derived from Multivariate MOF-74 for Supercapacitors. J. Mater. Chem. A 2015, 3, 20145-20152. [CrossRef]

71. Wang, S.; Li, L.; He, W.; Shao, Y.; Li, Y.; Wu, Y.; Hao, X. Oxygen Vacancy Modulation of Bimetallic Oxynitride Anodes toward Advanced Li-Ion Capacitors. Adv. Funct. Mater. 2020, 30, 2000350. [CrossRef]

72. Wang, Z.; Yan, X.; Wang, F.; Xiong, T.; Balogun, M.S.; Zhou, H.; Deng, J. Reduced Graphene Oxide Thin Layer Induced Lattice Distortion in High Crystalline $\mathrm{MnO}_{2}$ Nanowires for High-performance Sodium- and Potassium-ion Batteries and Capacitors. Carbon 2021, 174, 556-566. [CrossRef]

73. Su, X.; Wu, Q.; Li, J.; Xiao, X.; Lott, A.; Lu, W.; Sheldon, B.W.; Wu, J. Silicon-Based Nanomaterials for Lithium-Ion Batteries: A Review. Adv. Energy Mater. 2014, 4, 1300882. [CrossRef]

74. Vogl, U.; Lux, S.; Das, P.; Weber, A.; Placke, T.; Kostecki, R.; Winter, M. The Mechanism of SEI Formation on Single Crystal Si(100), $\mathrm{Si}(110)$ and $\mathrm{Si}(111)$ Electrodes. J. Electrochem. Soc. 2015, 162, A2281-A2288. [CrossRef]

75. Ulvestad, A.; Reksten, A.H.; Andersen, H.F.; Carvalho, P.A.; Jensen, I.J.T.; Nagell, M.U.; Mæhlen, J.P.; Kirkengen, M.; Koposov, A.Y. Crystallinity of Silicon Nanoparticles: Direct Influence on the Electrochemical Performance of Lithium Ion Battery Anodes. ChemElectroChem 2020, 7, 4349-4353. [CrossRef]

76. Lai, S.Y.; Knudsen, K.D.; Sejersted, B.T.; Ulvestad, A.; Mæhlen, J.P.; Koposov, A.Y. Silicon Nanoparticle Ensembles for Lithium-Ion Batteries Elucidated by Small-Angle Neutron Scattering. ACS Appl. Energy Mater. 2019, 2, 3220-3227. [CrossRef]

77. Shen, T.; Yao, Z.; Xia, X.; Wang, X.; Gu, C.; Tu, J. Rationally Designed Silicon Nanostructures as Anode Material for Lithium-Ion Batteries. Adv. Engineering Mater. 2018, 20, 1700591. [CrossRef]

78. Foss, C.E.L.; Müssig, S.; Svensson, A.M.; Vie, P.J.S.; Ulvestad, A.; Mæhlen, J.P.; Koposov, A.Y. Anodes for Li-ion batteries prepared from microcrystalline silicon and enabled by binder's chemistry and pseudo-self-healing. Sci. Rep. 2020, 10, 13193. [CrossRef] [PubMed]

79. Vogl, U.S.; Das, P.K.; Weber, A.Z.; Winter, M.; Kostecki, R.; Lux, S.F. Mechanism of Interactions between CMC Binder and Si Single Crystal Facets. Langmuir 2014, 30, 10299-10307. [CrossRef]

80. Saito, M.; Takahashi, K.; Ueno, K.; Seki, S. Electrochemical Charge/Discharge Properties of Li Pre-doped Si Nanoparticles for Use in Hybrid Capacitor Systems. J. Electrochem. Soc. 2016, 163, A3140-A3145. [CrossRef]

81. Saito, M.; Osawa, M.; Masuya, A.; Kawakatsu, K. Stabilization of Si Negative Electrode by Li Pre-doping Technique and the Application to a New Energy Storage System. Electrochemistry 2017, 85, 656-659. [CrossRef]

82. Liu, X.; Jung, H.-G.; Kim, S.-O.; Choi, H.-S.; Lee, S.; Moon, J.H.; Lee, J.K. Silicon/Copper Dome-patterned Electrodes for High-performance Hybrid Supercapacitors. Sci. Rep. 2013, 3, 3183. [CrossRef]

83. Shao, R.; Niu, J.; Zhu, F.; Dou, M.; Zhang, Z.; Wang, F. A Facile and Versatile Strategy towards High-performance Si Anodes for Li-ion Capacitors: Concomitant Conductive Network Construction and Dual-interfacial Engineering. Nano Energy 2019, 63, 103824. [CrossRef]

84. Aradilla, D.; Bidan, G.; Gentile, P.; Weathers, P.; Thissandier, F.; Ruiz, V.; Gómez-Romero, P.; Schubert, T.J.S.; Sahin, H.; Sadki, S. Novel Hybrid Micro-supercapacitor Based on Conducting Polymer Coated Silicon Nanowires for Electrochemical Energy Storage. RSC Adv. 2014, 4, 26462-26467. [CrossRef]

85. Lai, C.-M.; Kao, T.-L.; Tuan, H.-Y. Si Nanowires/Cu Nanowires Bilayer Fabric as a Lithium Ion Capacitor Anode with Excellent Performance. J. Power Sources 2018, 379, 261-269. [CrossRef]

86. Ge, M.; Fang, X.; Rong, J.; Zhou, C. Review of Porous Silicon Preparation and Its Application for Lithium-ion Battery Anodes. Nanotechnology 2013, 24, 422001. [CrossRef] [PubMed]

87. Korotcenkov, G. Porous Silicon: From Formation to Application; Taylor and Francis Group: Oxforshire, UK, 2016; Volume 1, pp. 187-216.

88. Oakes, L.; Westover, A.; Mares, J.W.; Chatterjee, S.; Erwin, W.R.; Bardhan, R.; Weiss, S.M.; Pint, C.L. Surface Engineered Porous Silicon for Stable, High Performance Electrochemical Supercapacitors. Sci. Rep. 2013, 3, 3020. [CrossRef] [PubMed]

89. Li, B.; Li, S.; Jin, Y.; Zai, J.; Chen, M.; Nazakat, A.; Zhan, P.; Huang, Y.; Qian, X. Porous Si@C Ball-in-ball Hollow Spheres for Lithium-ion Capacitors with Improved Energy and Power Densities. J. Mater. Chem. A 2018, 6, 21098-21103. [CrossRef] 
90. An, Y.-B.; Chen, S.; Zou, M.-M.; Geng, L.-B.; Sun, X.-Z.; Zhang, X.; Wang, K.; Ma, Y.-W. Improving Anode Performances of Lithium-ion Capacitors Employing Carbon-Si Composites. Rare Met. 2019, 38, 1113-1123. [CrossRef]

91. Huang, X.D.; Zhang, F.; Gan, X.F.; Huang, Q.A.; Yang, J.Z.; Lai, P.T.; Tang, W.M. Electrochemical Characteristics of Amorphous Silicon Carbide Film as a Lithium-ion Battery Anode. RSC Adv. 2018, 8, 5189-5196. [CrossRef]

92. Ulvestad, A.; Andersen, H.F.; Mæhlen, J.P.; Prytz, Ø.; Kirkengen, M. Long-term Cyclability of Substoichiometric Silicon Nitride Thin Film Anodes for Li-ion Batteries. Sci. Rep. 2017, 7, 13315. [CrossRef]

93. Liu, Z.; Yu, Q.; Zhao, Y.; He, R.; Xu, M.; Feng, S.; Li, S.; Zhou, L.; Mai, L. Silicon Oxides: A Promising Family of Anode Materials for Lithium-ion Batteries. Chem. Soc. Rev. 2019, 48, 285-309. [CrossRef]

94. Yi, R.; Chen, S.; Song, J.; Gordin, M.L.; Manivannan, A.; Wang, D. High-Performance Hybrid Supercapacitor Enabled by a High-Rate Si-based Anode. Adv. Funct. Mater. 2014, 24, 7433-7439. [CrossRef]

95. Kim, M.; Oh, I.; Kim, J. Carbonization Temperature Dependence of Pore Structure of Silicon Carbide Spheres and Their Electrochemical Capacitive Properties as Supercapacitors. Ceram. Int. 2016, 42, 3947-3958. [CrossRef]

96. Halim, M.; Liu, G.; Ardhi, R.E.A.; Hudaya, C.; Wijaya, O.; Lee, S.-H.; Kim, A.Y.; Lee, J.K. Pseudocapacitive Characteristics of Low-Carbon Silicon Oxycarbide for Lithium-Ion Capacitors. ACS Appl. Mater. Interfaces 2017, 9, 20566-20576. [CrossRef]

97. Lakraychi, A.E.; Vlad, A. Organic Batteries-The Route towards Sustainable Electrical Energy Storage Technologies. Chim. Nouv 2018, 127, 1-9.

98. Armand, M.; Tarascon, J.M. Building Better Batteries. Nature 2008, 451, 652-657. [CrossRef] [PubMed]

99. Chen, H.; Armand, M.; Demailly, G.; Dolhem, F.; Poizot, P.; Tarascon, J.-M. From Biomass to a Renewable Lix $\mathrm{C}_{6} \mathrm{O}_{6} \mathrm{Organic}$ Electrode for Sustainable Li-Ion Batteries. ChemSusChem 2008, 1, 348-355. [CrossRef]

100. Chen, H.; Armand, M.; Courty, M.; Jiang, M.; Grey, C.P.; Dolhem, F.; Tarascon, J.-M.; Poizot, P. Lithium Salt of Tetrahydroxybenzoquinone: Toward the Development of a Sustainable Li-Ion Battery. J. Am. Chem. Soc. 2009, 131, 8984-8988. [CrossRef] [PubMed]

101. Nishide, H.; Oyaizu, K. Toward Flexible Batteries. Science 2008, 319, 737-738. [CrossRef]

102. Hasan, S.S.; Yamashita, E.; Baniulis, D.; Cramer, W.A. Quinone-dependent Proton Transfer Pathways in the Photosynthetic Cytochrome b6f Complex. Proc. Natl. Acad. Sci. USA 2013, 110, 4297-4302. [CrossRef]

103. Deuchert, K.; Hünig, S. Multistage Organic Redox Systems-A General Structural Principle. Angew. Chem. Int. Ed. 1978, 17, 875-886. [CrossRef]

104. Gottis, S.; Barrès, A.-L.; Dolhem, F.; Poizot, P. Voltage Gain in Lithiated Enolate-Based Organic Cathode Materials by Isomeric Effect. ACS Appl. Mater. Interfaces 2014, 6, 10870-10876. [CrossRef] [PubMed]

105. Armand, M.; Grugeon, S.; Vezin, H.; Laruelle, S.; Ribière, P.; Poizot, P.; Tarascon, J.M. Conjugated Dicarboxylate Anodes for Li-ion Batteries. Nat. Mater. 2009, 8, 120-125. [CrossRef]

106. Renault, S.; Mihali, V.A.; Brandell, D. Optimizing the Electrochemical Performance of Water-soluble Organic Li-ion Battery Electrodes. Electrochem. Commun. 2013, 34, 174-176. [CrossRef]

107. Fédèle, L.; Sauvage, F.; Bois, J.; Tarascon, J.-M.; Bécuwe, M. Lithium Insertion/De-Insertion Properties of $\pi$-Extended NaphthylBased Dicarboxylate Electrode Synthesized by Freeze-Drying. J. Electrochem. Soc. 2013, 161, A46-A52. [CrossRef]

108. Lee, J.; Kim, H.; Park, M.J. Long-Life, High-Rate Lithium-Organic Batteries Based on Naphthoquinone Derivatives. Chem. Mater. 2016, 28, 2408-2416. [CrossRef]

109. Ogihara, N.; Yasuda, T.; Kishida, Y.; Ohsuna, T.; Miyamoto, K.; Ohba, N. Organic Dicarboxylate Negative Electrode Materials with Remarkably Small Strain for High-Voltage Bipolar Batteries. Angew. Chem. Int. Ed. 2014, 53, 11467-11472. [CrossRef] [PubMed]

110. Wang, Y.; Deng, Y.; Qu, Q.; Zheng, X.; Zhang, J.; Liu, G.; Battaglia, V.S.; Zheng, H. Ultrahigh-Capacity Organic Anode with High-Rate Capability and Long Cycle Life for Lithium-Ion Batteries. ACS Energy Lett. 2017, 2, 2140-2148. [CrossRef]

111. Kapaev, R.R.; Zhidkov, I.S.; Kurmaev, E.Z.; Stevenson, K.J.; Troshin, P.A. Hexaazatriphenylene-based Polymer Cathode for Fast and Stable Lithium-, Sodium- and Potassium-ion Batteries. J. Mater. Chem. A 2019, 7, 22596-22603. [CrossRef]

112. Bonaccorso, F.; Colombo, L.; Yu, G.; Stoller, M.; Tozzini, V.; Ferrari, A.C.; Ruoff, R.S.; Pellegrini, V. Graphene, Related Twodimensional Crystals, and Hybrid Systems for Energy Conversion and Storage. Science 2015, 347, 1246501. [CrossRef]

113. Liu, Y.; Peng, X. Recent Advances of Supercapacitors Based on Two-dimensional Materials. Appl. Mater. Today 2017, 8, 104-115. [CrossRef]

114. Han, Y.; Ge, Y.; Chao, Y.; Wang, C.; Wallace, G.G. Recent Progress in 2D Materials for Flexible Supercapacitors. J. Energy Chem. 2018, 27, 57-72. [CrossRef]

115. Sahoo, R.; Pal, A.; Pal, T. 2D Materials for Renewable Energy Storage Devices: Outlook and Challenges. Chem. Commun. 2016, 52, 13528-13542. [CrossRef] [PubMed]

116. Zhang, X.; Wang, L.; Liu, W.; Li, C.; Wang, K.; Ma, Y. Recent Advances in MXenes for Lithium-Ion Capacitors. ACS Omega 2020, 5 , 75-82. [CrossRef]

117. Anasori, B.; Lukatskaya, M.R.; Gogotsi, Y. 2D Metal Carbides and Nitrides (MXenes) for Energy Storage. Nat. Rev. Mater. 2017, 2, 16098. [CrossRef]

118. Zhu, Q.; Li, J.; Simon, P.; Xu, B. Two-dimensional MXenes for Electrochemical Capacitor Applications: Progress, Challenges and Perspectives. Energy Storage Mater. 2021, 35, 630-660. [CrossRef]

119. Naguib, M.; Kurtoglu, M.; Presser, V.; Lu, J.; Niu, J.; Heon, M.; Hultman, L.; Gogotsi, Y.; Barsoum, M.W. Two-Dimensional Nanocrystals Produced by Exfoliation of $\mathrm{Ti}_{3} \mathrm{AlC}_{2}$. Adv. Mater. 2011, 23, 4248-4253. [CrossRef] [PubMed] 
120. Ghidiu, M.; Lukatskaya, M.R.; Zhao, M.-Q.; Gogotsi, Y.; Barsoum, M.W. Conductive Two-dimensional Titanium Carbide 'Clay' with High Volumetric Capacitance. Nature 2014, 516, 78-81. [CrossRef]

121. Halim, J.; Lukatskaya, M.R.; Cook, K.M.; Lu, J.; Smith, C.R.; Näslund, L.-Å.; May, S.J.; Hultman, L.; Gogotsi, Y.; Eklund, P.; et al. Transparent Conductive Two-Dimensional Titanium Carbide Epitaxial Thin Films. Chem. Mater. 2014, 26, 2374-2381. [CrossRef] [PubMed]

122. Yu, P.; Cao, G.; Yi, S.; Zhang, X.; Li, C.; Sun, X.; Wang, K.; Ma, Y. Binder-free 2D Titanium Carbide (MXene)/Carbon Nanotube Composites for High-performance Lithium-ion Capacitors. Nanoscale 2018, 10, 5906-5913. [CrossRef]

123. Naoi, K.; Ishimoto, S.; Miyamoto, J.-I.; Naoi, W. Second Generation 'Nanohybrid Supercapacitor': Evolution of Capacitive Energy Storage Devices. Energy Environ. Sci. 2012, 5, 9363-9373. [CrossRef]

124. Kodama, R.; Terada, Y.; Nakai, I.; Komaba, S.; Kumagai, N. Electrochemical and in situ XAFS-XRD Investigation of $\mathrm{Nb}_{2} \mathrm{O}_{5}$ for Rechargeable Lithium Batteries. J. Electrochem. Soc. 2006, 153, A583. [CrossRef]

125. Lu, X.; Jian, Z.; Fang, Z.; Gu, L.; Hu, Y.-S.; Chen, W.; Wang, Z.; Chen, L. Atomic-scale Investigation on Lithium Storage Mechanism in $\mathrm{TiNb}_{2} \mathrm{O}_{7}$. Energy Environ. Sci. 2011, 4, 2638-2644. [CrossRef] 